\title{
Hydroclimatic variability in the Levant during the early last glacial ( 117-75 ka) derived from micro-facies analyses of deep Dead Sea sediments
}

\author{
I. Neugebauer ${ }^{1}$, M. J. Schwab ${ }^{1}$, N. D. Waldmann ${ }^{2}$, R. Tjallingii ${ }^{1}$, U. Frank ${ }^{1}$, E. Hadzhiivanova ${ }^{2}$, R. Naumann ${ }^{3}$, \\ N. Taha' ${ }^{2}$, A. Agnon ${ }^{4}$, Y. Enzel ${ }^{4}$, and A. Brauer ${ }^{1,5}$ \\ ${ }^{1}$ GFZ German Research Centre for Geosciences, Section 5.2 - Climate Dynamics and Landscape Evolution, \\ Telegrafenberg, 14473 Potsdam, Germany \\ ${ }^{2}$ University of Haifa, Department of Marine Geosciences, Leon H. Charney School of Marine Sciences, \\ Mount Carmel 31905, Israel \\ ${ }^{3}$ GFZ German Research Centre for Geosciences, Section 3.1 - Inorganic and Isotope Geochemistry, \\ Telegrafenberg, 14473 Potsdam, Germany \\ ${ }^{4}$ The Hebrew University of Jerusalem, The Fredy \& Nadine Herrmann Institute of Earth Sciences, \\ Givat Ram, Jerusalem 91904, Israel \\ ${ }^{5}$ University of Potsdam, Institute of Earth and Environmental Science, Karl-Liebknecht-Str. 24-25, \\ 14476 Potsdam-Golm, Germany \\ Correspondence to: I. Neugebauer (inaneu@gfz-potsdam.de)
}

Received: 18 June 2015 - Published in Clim. Past Discuss.: 11 August 2015

Revised: 17 December 2015 - Accepted: 30 December 2015 - Published: 18 January 2016

\begin{abstract}
The new sediment record from the deep Dead Sea basin (ICDP core 5017-1) provides a unique archive for hydroclimatic variability in the Levant. Here, we present highresolution sediment facies analysis and elemental composition by micro-X-ray fluorescence ( $\mu \mathrm{XRF}$ ) scanning of core 5017-1 to trace lake levels and responses of the regional hydroclimatology during the time interval from ca. 117 to $75 \mathrm{ka}$, i.e. the transition between the last interglacial and the onset of the last glaciation. We distinguished six major micro-facies types and interpreted these and their alterations in the core in terms of relative lake level changes. The two end-member facies for highest and lowest lake levels are (a) up to several metres thick, greenish sediments of alternating aragonite and detrital marl laminae (aad) and (b) thick halite facies, respectively. Intermediate lake levels are characterised by detrital marls with varying amounts of aragonite, gypsum or halite, reflecting lower-amplitude, shorter-term variability. Two intervals of pronounced lake level drops occurred at $\sim 110$ $108 \pm 5$ and $\sim 93-87 \pm 7 \mathrm{ka}$. They likely coincide with stadial conditions in the central Mediterranean (Melisey I and II pollen zones in Monticchio) and low global sea levels during
\end{abstract}

Marine Isotope Stage (MIS) 5d and 5b. However, our data do not support the current hypothesis of an almost complete desiccation of the Dead Sea during the earlier of these lake level low stands based on a recovered gravel layer. Based on new petrographic analyses, we propose that, although it was a low stand, this well-sorted gravel layer may be a vestige of a thick turbidite that has been washed out during drilling rather than an in situ beach deposit. Two intervals of higher lake stands at $\sim 108-93 \pm 6$ and $\sim 87-75 \pm 7$ ka correspond to interstadial conditions in the central Mediterranean, i.e. pollen zones St. Germain I and II in Monticchio, and Greenland interstadials (GI) $24+23$ and 21 in Greenland, as well as to sapropels S4 and S3 in the Mediterranean Sea. These apparent correlations suggest a close link of the climate in the Levant to North Atlantic and Mediterranean climates during the time of the build-up of Northern Hemisphere ice shields in the early last glacial period. 


\section{Introduction}

The Dead Sea and its Pleistocene precursor lakes Amora, Samra and Lisan (e.g. Bartov et al., 2003; Torfstein et al., 2009; Waldmann et al., 2009) experienced major lake level fluctuations in the past as a sensitive response to changing hydroclimatic conditions in the lake's watershed (e.g. Enzel et al., 2008). The lakes expanded during glacial intervals due to up to twice modern precipitation, whereas interglacials are generally characterised by a lake contraction due to reduced precipitation and runoff (Enzel et al., 2008; Rohling, 2013). Hence, the last glacial Lake Lisan, which occupied the Dead Sea basin between $\sim 70$ and $14 \mathrm{ka}$, reached up to $\sim 270 \mathrm{~m}$ higher lake stands than the Holocene Dead Sea and the last interglacial Lake Samra (e.g. Bartov et al., 2002, 2007; Waldmann et al., 2007; Torfstein et al., 2013). The highest amplitudes of lake level drops occurred at the glacial to interglacial transitions triggered by lower rainfall (e.g. Yechieli et al., 1993; Bartov et al., 2007; Waldmann et al., 2009; Stein et al., 2010). For example, the fresher Lake Lisan water body turned into the hypersaline Holocene Dead Sea during the last termination leading to the deposition of a thick halite sequence during the early Holocene $(\sim 11-10 \mathrm{ka}$; e.g. Stein et al., 2010).

Less information is available about lake level changes during the transition from interglacial to glacial climate conditions. Previous studies from exposed sediment sections of the Samra Formation at the south-western margin of the Dead Sea suggested a relatively shallow Lake Samra from ca. 135 to $75 \mathrm{ka}$ (Waldmann et al., 2007, 2009, 2010). The main lake level rise at the transition from Lake Samra to Lake Lisan was assumed from a sedimentological change from sand deposits to sediments of alternating fine laminae of aragonite and detritus at a major unconformity $\sim 75-70 \mathrm{ka}$ (e.g. Waldmann et al., 2009; Torfstein et al., 2013). However, the early glacial time interval between the last interglacial low stand (Lake Samra) and the full glacial high stand (Lake Lisan), i.e. coinciding with Marine Isotope Stage (MIS) 5d to 5a, is not well represented in the exposed sediments (Waldmann et al., 2009).

Sediments from this time interval have been for the first time recovered by the ICDP Dead Sea Deep Drilling Project (DSDDP) from the deepest part of the Dead Sea basin (Neugebauer et al., 2014). Based on a new chronology and interpretation of a well-sorted gravel deposit, Torfstein et al. (2015) inferred an almost complete drawdown of the Dead Sea leading to a sedimentary hiatus between 116 and $110 \mathrm{ka}$ at around MIS 5d, which is considered the most extreme lake level drop during the last $\sim 220 \mathrm{ka}$, i.e. the time period covered by the DSDDP sediment record. Furthermore, Torfstein et al. (2015) suggest moisture supply through the African monsoon to the southern Levant during more humid intervals in the early last glacial, which are considered to coincide with MIS 5c and 5a, whereas marine and terrestrial records from across the Mediterranean region responded to long-term orbitally induced temperature fluctuations, ice sheet waxing and waning in the Northern Hemisphere and climatic changes in the North Atlantic (e.g. Tzedakis, 2005; Martin-Puertas et al., 2014).

In this study, we apply a combination of petrographic, micro-facies and high-resolution X-ray fluorescence (XRF) analyses to investigate in more detail the sedimentological changes in the new ICDP Dead Sea record between the last interglacial and the onset of Lake Lisan $(\sim 117-75 \mathrm{ka})$. These sediments and their alterations serve as indicators for hydroclimatic variations in the southern Levant. In addition, we focus on the sedimentology of the gravel layer to add information on the drawdown hypothesis of the Dead Sea (Stein et al., 2011; Torfstein et al., 2015).

\section{Regional setting}

With a lake level of $429 \mathrm{~m}$ (in 2015) below mean sea level (mb.m.s.l.) and a water depth of ca. $300 \mathrm{~m}$ the Dead Sea is located in one of the lowest continental depressions on earth. The basin is bounded by the Judean Mountains on the west and the Jordan Plateau on the east, rising to heights of $\sim 1000$ and $\sim 1200 \mathrm{~m}$ above mean sea level, respectively (Fig. 1). The modern watershed of the lake, which is one of the largest in the Levant $\left(\sim 40000 \mathrm{~km}^{2}\right)$, experiences subhumid (> $1000 \mathrm{~mm} \mathrm{yr}^{-1}$ in the northernmost point) to semiarid Mediterranean climate in its north and arid to hyperarid ( $\sim 30 \mathrm{~mm} \mathrm{yr}^{-1}$ in the southernmost point) conditions in the southern part characterised by winter rain of the SaharoArabian environment. These climate conditions combined with the particular steep topography of the basin margins create hyperarid conditions at the lake itself. The modern Dead Sea is a hypersaline calcium chloride brine (e.g. Katz et al., 1977; Lensky et al., 2005) and a terminal lake, mainly fed by the Jordan River (Fig. 1). Precipitation primarily arrives in the watershed in autumn to late spring (OctoberMay) through eastern Mediterranean mid-latitude cyclones (Cyprus Lows; Ziv et al., 2006; Enzel et al., 2008) and tropical plumes in winter and spring (also termed subtropical jet storms by Kahana et al., 2002; Rubin et al., 2007). Occasionally, the region is influenced by the Active Red Sea Trough from the south during autumn and winter (e.g. Enzel et al., 2008) with sources of its moisture also in the Mediterranean. The geology of the catchment is predominantly characterised by Cretaceous carbonate sedimentary rocks, with some Palaeozoic to Mesozoic sandstones and Pleistocene volcanic units (Bentor, 1961; Sneh et al., 1998).

\section{Material and methods}

\subsection{Dead Sea deep-basin core 5017-1}

The 5017-1 sediment core from the deep Dead Sea basin $\left(31^{\circ} 30^{\prime} 29^{\prime \prime} \mathrm{N}, 35^{\circ} 28^{\prime} 16^{\prime \prime} \mathrm{E}\right.$; ca. $300 \mathrm{~m}$ water depth in 2010 ; sediment surface $\sim 725$ m b.m.s.l.; Fig. 1) was obtained dur- 

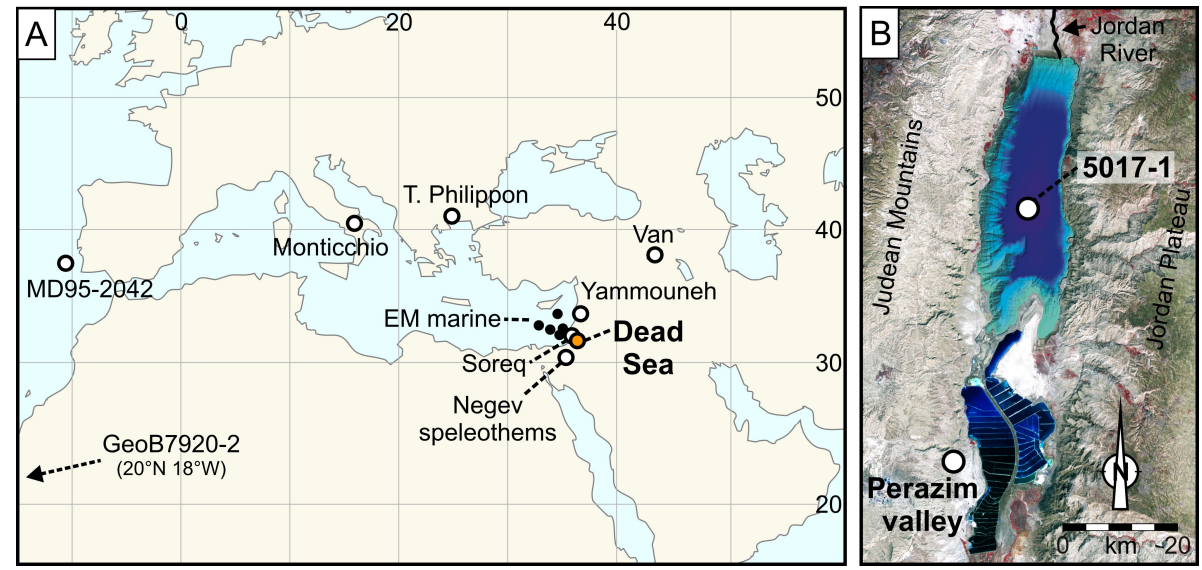

Figure 1. (a) Location of Mediterranean records discussed in the text; EM marine - eastern Mediterranean marine cores (Cheddadi and Rossignol-Strick, 1995; Almogi-Labin et al., 2009); Negev speleothems - various caves in the northern, central and southern Negev (Vaks et al., 2010); for references of the other records the reader is referred to the text. (b) Map of the Dead Sea (NASA image by R. Simmon using Landsat data, 2011, from USGS, www.visibleearth.nasa.gov/), with bathymetry of the northern Dead Sea basin from Sade et al. (2014), 5017-1 coring location, Perazim Valley Samra outcrop PZ-7 (Waldmann et al., 2009).

ing the drilling campaign of the ICDP Dead Sea Deep Drilling Project (DSDDP) in winter 2010-2011 (Stein et al., 2011). The record is $\sim 455 \mathrm{~m}$ long and comprises two full glacial-interglacial cycles (Neugebauer et al., 2014; Torfstein et al., 2015). Here, we focus on a $\sim 65 \mathrm{~m}$ long section from $\sim 180$ to $\sim 245 \mathrm{~m}$ below lake floor (m b.l.f.). Sediment facies were described with an accuracy of $1 \mathrm{~cm}$ based on linescanning images of the split sediment cores. Magnetic susceptibility data in $1 \mathrm{~mm}$ resolution were routinely obtained for the entire 5017-1 record (see Neugebauer et al., 2014, for details).

\subsection{Micro-facies analyses}

For micro-facies analyses we applied a combination of petrographic thin-section microscopy and high-resolution $\mu \mathrm{XRF}$ element scanning. A total of 26 large-scale thin-section samples $(10 \times 2 \mathrm{~cm})$ were prepared representing changes in facies types along the section. Preparation largely followed the standard procedure for soft sediments (e.g. Brauer et al., 1999) but were performed under dry conditions to avoid salt crystallisation during the preparation process. Thin sections were analysed with a petrographic microscope (Leica DMLP) and images were taken with a digital camera (Olympus DP72). Fluorescence was analysed using a Nikon AZ100M microscope, operated with violet and polarised light conditions, and Nikon photo software (NIS Elements AR 4.3).

The $\mu$ XRF measurements were acquired every $200 \mu \mathrm{m}$ for $10 \mathrm{~s}$ using the ITRAX $\mu \mathrm{XRF}$ core scanner at GFZ, Germany. The core scanner is equipped with a $\mathrm{Cr}$ tube operated at $30 \mathrm{kV}$ and $30 \mathrm{~mA}$ to irradiate the split-core sediment surface. This non-destructive method acquires element intensities of $\mathrm{Si}, \mathrm{S}, \mathrm{Cl}, \mathrm{K}, \mathrm{Ca}, \mathrm{Ti}, \mathrm{Fe}, \mathrm{Br}$ and $\mathrm{Sr}$ (Neugebauer et al., 2014), which are presented as count rates (counts per second - cps). The element intensity records reflect relative changes in the composition of the Dead Sea sediments, but they are also influenced by physical sediment properties (e.g. density, water content, grain size) and the sample geometry. The easiest and most convenient way to minimise the physical and geometrical sample effects is by the transformation of element intensities into ratios or log ratios (Weltje and Tjallingii, 2008).

\subsection{Grain size analyses and gravel petrography}

Laminated sediments were sampled for grain size distributions with $1 \mathrm{~cm}^{3}$ sample volume at $1-3 \mathrm{~cm}$ vertical resolution and a total of 363 samples. Sample preparation included decomposing organic matter using $30 \mathrm{~mL} \mathrm{H}_{2} \mathrm{O}_{2}(30 \%)$ and distilled water $(1: 1$ concentration) and breaking aggregates with Calgon detergent $\left(\left(\mathrm{NaPO}_{3}\right)_{6}, 1 \%\right)$ and ultrasonic bath. The particle size distribution was measured using an LS 13 320 laser diffraction particle size analyser for (1) the total sample and (2) the carbonate-free sample after dissolution through $\mathrm{HCl}(32 \%$, dilution of $1: 9$ with distilled water). Less than $1 \mathrm{~g}$ of sediment was required for measurement.

In total, 22 gravel layers detected in core 5017-1 were sampled for petrographic analyses. The samples were wetsieved for five grain size fractions $(>4,2-4,1-2,0.5-1$ and $<0.5 \mathrm{~mm}$ ), for which strewn slides were prepared for microscopic inspections. Here, we focus on two gravel units occurring within the studied core section (180-245 m b.l.f.).

\subsection{XRD and $\mathrm{TOC} / \mathrm{CaCO}_{3}$ measurements}

For X-ray powder diffraction (XRD) measurements 25 samples were collected from about the same depths as thin sections to complement microscopic inspections. Powder X-ray 
patterns were collected using a PANalytical Empyrean powder diffractometer with $\mathrm{Cu} \mathrm{K} \alpha$ radiation, automatic divergent and antiscatter slits and a PIXcel ${ }^{3 \mathrm{D}}$ detector. The diffraction data were recorded from $5^{\circ}$ to $85^{\circ} 2 \Theta$ via a continuous scan with a step size of 0.013 and a scan time of 60 s per step. The generator settings were $40 \mathrm{kV}$ and $40 \mathrm{~mA}$.

Total organic carbon (TOC) and calcium carbonate $\left(\mathrm{CaCO}_{3}\right)$ contents have been determined from 19 of these samples using an elemental analyser (EA3000-CHNS Eurovector). First, 5-10 mg dried and homogenised sample material was weighed in Sn capsules for total carbon (TC) determination. Subsequently, second sample aliquots of 3-4 mg of the samples were decalcified in $\mathrm{Ag}$ capsules in three steps through treatment with (1) $3 \% \mathrm{HCl}$, (2) $20 \% \mathrm{HCl}$ and (3) drying at $75^{\circ} \mathrm{C}$ for TOC determination. Data were calibrated with standards (BBOT, sulfanilamide, and for TOC additionally Boden 3) and empty $\mathrm{Sn}$ and $\mathrm{Ag}$ capsules. The relative standard deviation is $<1 \%$. $\mathrm{CaCO}_{3}$ contents were calculated from the difference of TC-TOC.

\section{Results}

\subsection{Micro-facies, sedimentology and geochemistry}

The sediments of the analysed $\sim 65 \mathrm{~m}$ long section of core 5017-1 mainly consist of laminated marl of the aad facies (alternating aragonite and detritus; e.g. Machlus et al., 2000), gypsum and halite deposits (Neugebauer et al., 2014). Commonly, detrital material is composed of clay to silt-sized calcite, quartz, dolomite and minor feldspar and clay minerals. The thickness of detrital layers ranges from $<1 \mathrm{~mm}$ to several centimetres and their colour is greyish to black, if iron sulfides are present (pyrite or greigite), or brownish and greenish, if terrestrial organic or algal remains are dominant. Aragonite formed as 5-15 $\mu \mathrm{m}$ small stellate aggregates of orthorhombic crystals building $\sim 0.1-4 \mathrm{~mm}$ thick white laminae. Monoclinic, euhedral $\sim 10-60 \mu \mathrm{m}$ gypsum crystals build $\sim 0.2-3 \mathrm{~cm}$ thick beige layers. Larger, up to $1 \mathrm{~mm}$ gypsum crystals appear scattered within detrital layers. Cubic halite crystals ranging in length from $\sim 1 \mathrm{~mm}$ to several centimetres are either embedded in predominantly detrital marl or build thick deposits. These thick halite deposits contain only minor detrital material and are often layered.

Six micro-facies types were identified (Fig. 2):

1. green aad: alternating white aragonite and greenish detrital marl laminae ( $\sim 1 \mathrm{~mm}$ thick couplets; Fig. $2 \mathrm{a}$ ), the greenish laminae exhibit some diatoms and very strong fluorescence pointing to a significant amount of chlorophyll preserved in the sediment (Fig. 2f);

2. aad-n: alternating white aragonite and greyish detrital marl laminae $(\sim 1 \mathrm{~mm}$ thick couplets, occurrence as normal type; defined by Machlus et al., 2000);
3. aad-II: alternating white aragonite and greyish detrital marl laminae with thicker aragonite layers than normal type ( $1-5 \mathrm{~mm}$ thick couplets, Fig. $2 \mathrm{~b}$ );

4. gd: well laminated to massive, centimetre-thick gypsum deposits and detrital marl (Fig. 2d);

5. hd: cubic halite crystals $(\mathrm{mm}-\mathrm{cm})$ scattered in detrital marl;

6. $\mathrm{hh} / \mathrm{hh}$ : layered or homogeneous consolidated halite; the layered type often alternates with thin detrital marl laminae (Fig. 2e).

In addition, up to $1.7 \mathrm{~m}$ thick graded layers and up to $3 \mathrm{~m}$ thick slump deposits are predominantly associated with the aad micro-facies types and less frequent and thinner in the halite-dominated sections. In centimetre to tens of centimetre thick basal layers of 22 thick turbidites and slump deposits, matrix-supported $\sim 2-8 \mathrm{~mm}$ sized, angular to rounded gravels occur. In the studied section of core 5017-1, four such mass-waste deposits with gravel-rich basal layers were identified at composite depths of $\sim 233.5, \sim 192.8, \sim 183.5$ and $\sim 183 \mathrm{~m}$ (Fig. 4 ), of which the $\sim 58 \mathrm{~cm}$ thick turbidite at $\sim 233.5 \mathrm{~m}$ depth was analysed in detail (Fig. 3). The matrixsupported gravels are composed of carbonates (limestone, dolomite, with a presence of aragonite) in the form of sparite, (bio)micrite or peloid, and sulfates (gypsum, anhydrite) as well as halite and minor quartz. The fine and medium gravel fractions constitute $\sim 40 \%$ of the total dry weight (Fig. 3b).

In one exceptional case at $\sim 239 \mathrm{~m}$ composite depth, a $\sim 35 \mathrm{~cm}$ thick layer of well-sorted gravels with $<2 \%$ clay to sand matrix appears (Figs. 3 and 4). The petrographic composition of this gravel deposit is identical to that of the other mud-supported gravels (Fig. 3). This gravel layer is from a core section that suffered a major loss of core material during the drilling process (core 5017-1-A-92-1). From the $130 \mathrm{~cm}$ long core drive only a cumulative thickness of $35 \mathrm{~cm}$ gravels and almost no fine material were recovered in the liner. Therefore, the sedimentological contacts to over- and underlying sediments are not preserved and are unknown (Fig. 3). Unfortunately, this prevents investigation of sediment structures in the context of the complete depositional environment. Interestingly, in the $10 \mathrm{~cm}$ wide core catcher of this core drive, matrix-supported gravel has been caught. This core catcher sample largely resembles the basal layers of the above-mentioned thick turbidites and slumps.

Median grain size values of the laminated sediments, excluding the halite-facies types hd and $\mathrm{lh} / \mathrm{hh}$, vary between $\sim 7$ and $\sim 10 \mu \mathrm{m}$ for samples with and without $\mathrm{CaCO}_{3}$ (i.e. after dissolution of $\mathrm{CaCO}_{3}$; see the Supplement), respectively. These grain size distributions indicate mainly clay ( $\sim 54$ and $\sim 43 \%$ with and without $\mathrm{CaCO}_{3}$, respectively), very fine silt $\left(\sim 45\right.$ and $\sim 55 \%$ with and without $\mathrm{CaCO}_{3}$, respectively) and very little sand $(\sim 0.1$ and $\sim 0.9 \%$ with and without $\mathrm{CaCO}_{3}$, respectively). Gypsum-detritus samples 
(a) greenish aad

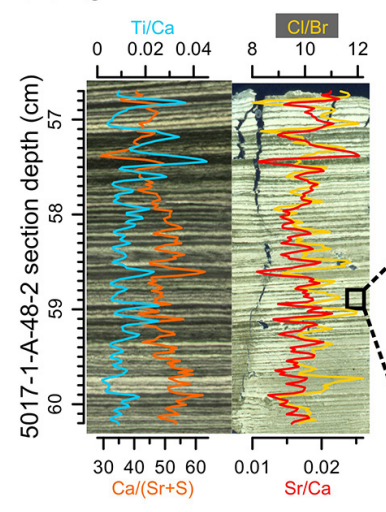

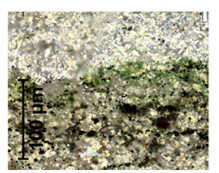

aragonite, detritus, iron sulfides

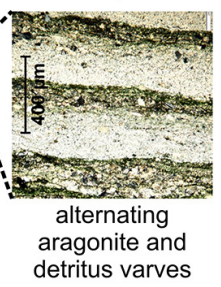

(d) gypsum and detrital marl ( $g d$ )

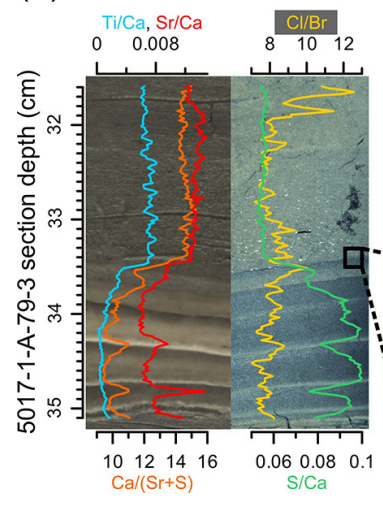

(g)

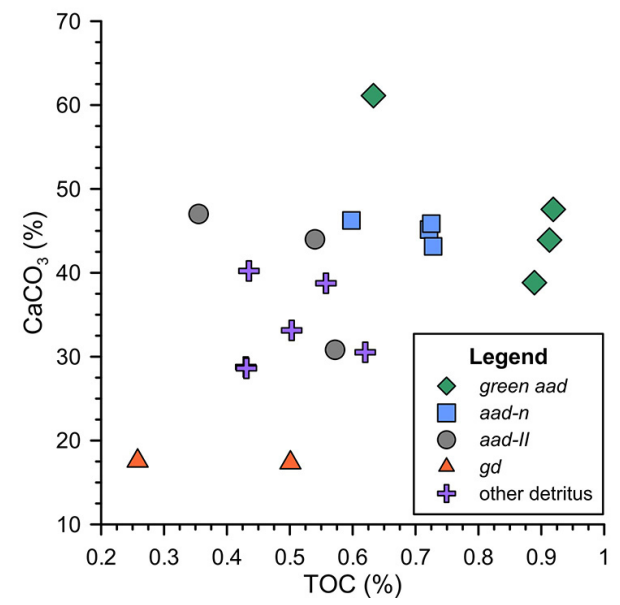

(b) aad-II

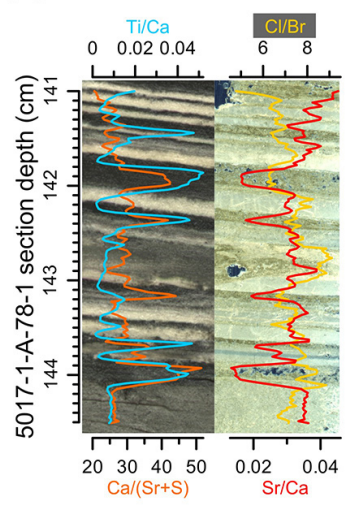

(e) layered halite $(/ h)$

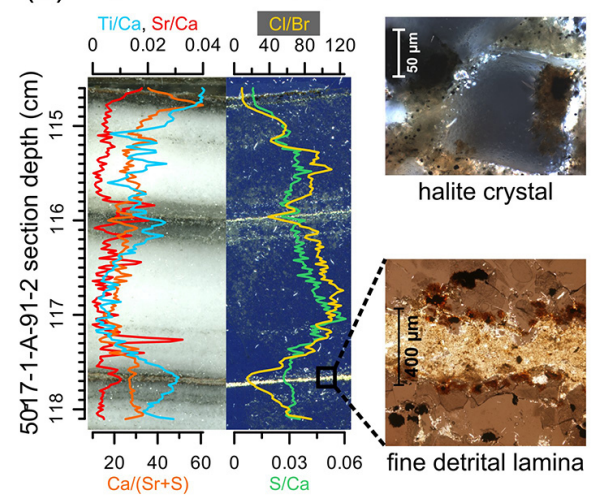

(h) (c) graded layer

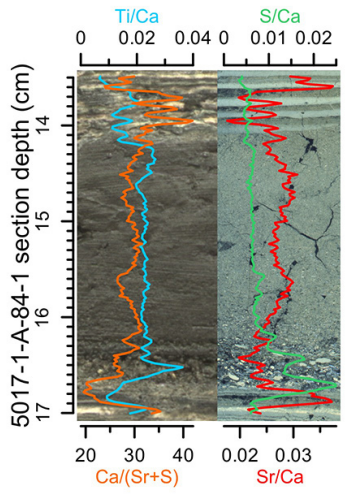

(f) fluorescence

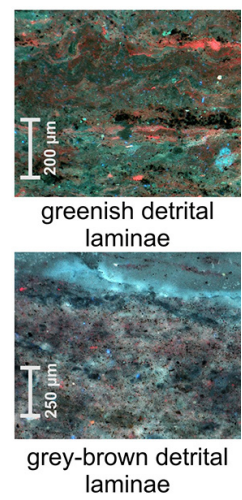

LU-II

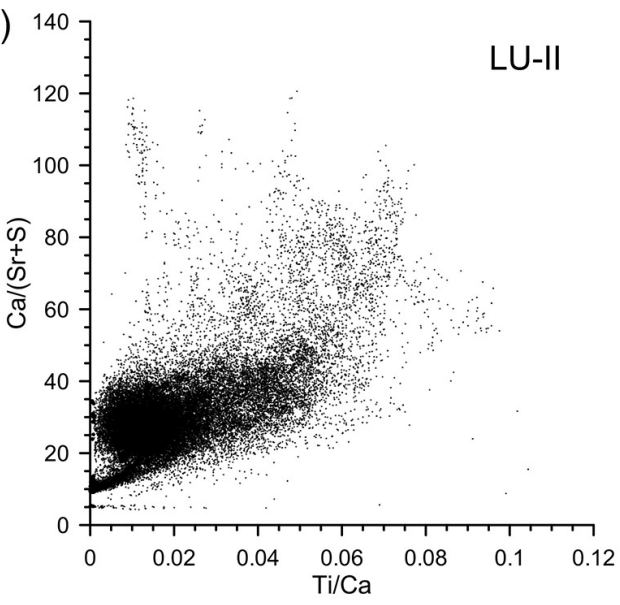

Figure 2. Micro-facies (core photos, polarised thin-section scans and microscopic images with varying magnification and polarisation conditions) and $\mu \mathrm{XRF}$ characteristics (element ratios): (a) green aad facies with peaks in $\mathrm{Sr} / \mathrm{Ca}$ typical for aragonite layers and peaks in $\mathrm{Ti} / \mathrm{Ca}$ and $\mathrm{Ca} /(\mathrm{Sr}+\mathrm{S})$ indicating detrital layers; (b) aad-II facies containing greyish detritus and thicker aragonite layers than the green aad facies; (c) example of a mass-waste deposit: graded layer with high $\mathrm{Ti} / \mathrm{Ca}$ ratio and increased $\mathrm{S} / \mathrm{Ca}$ at the base due to diagenetic gypsum; (d) gd facies characterised by a high S / Ca ratio; (e) lh facies with high $\mathrm{Cl} / \mathrm{Br}$ and positively correlated S / Ca, but peaks of all other elements only in the thin detrital laminae; (f) fluorescence (violet light) microscope images of greenish detrital laminae (upper photo, core section 5017-A-1-87-1, at $\sim 72 \mathrm{~cm}$ ) with very strong fluorescence (red colour) and greyish-brownish detrital laminae (lower photo, core section 5017-1-A-78-1, at $\sim 140 \mathrm{~cm}$ ) that are characterised by a weaker fluorescence; (g) correlation plot of TOC against $\mathrm{CaCO}_{3}$ contents of 19 samples distinguished for different micro-facies types; (h) correlation plot of the two detrital fractions as derived from $\mu$ XRF element scanning, exemplary for lithological unit (LU) II: Ti / Ca as proxy for the siliciclastic detrital fraction and $\mathrm{Ca} /(\mathrm{Sr}+\mathrm{S})$ as proxy for the detrital carbonate fraction, $R^{2}=0.4$. 


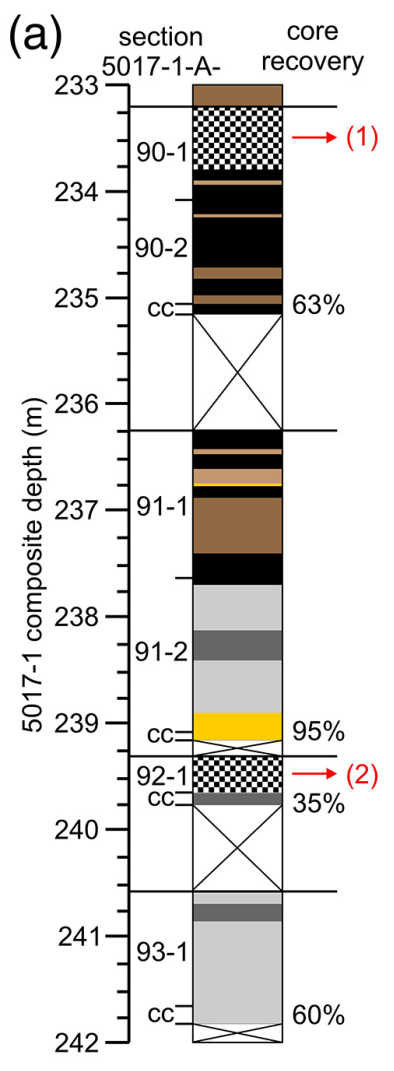

(1) $1-A-90-1$

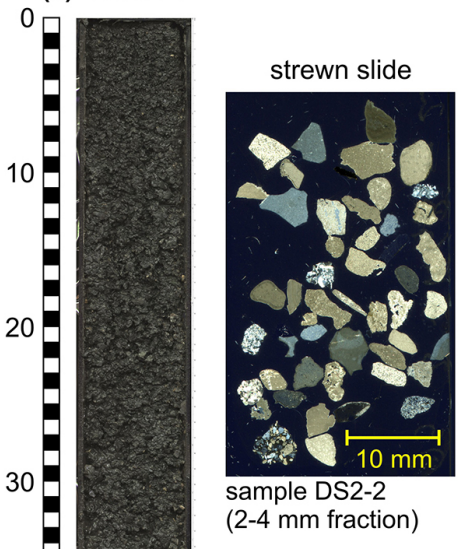

(2) $1-\mathrm{A}-92-1$

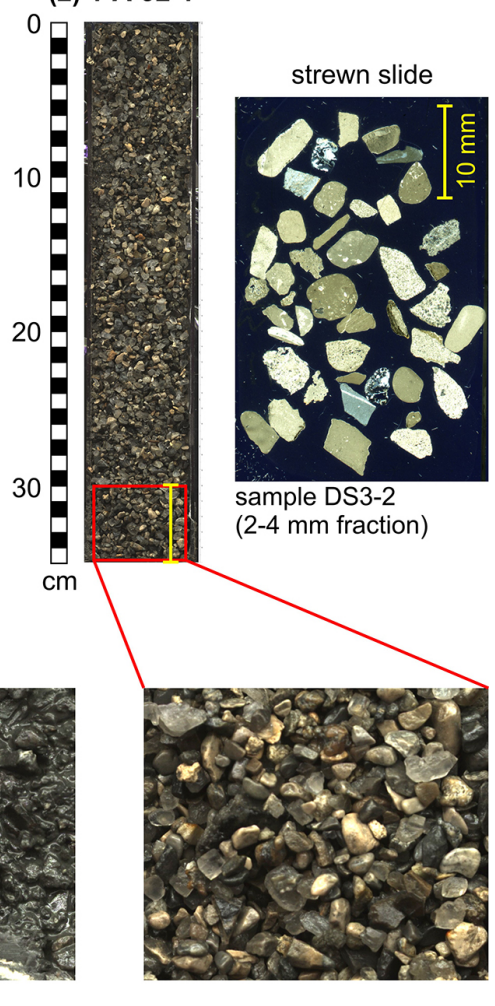

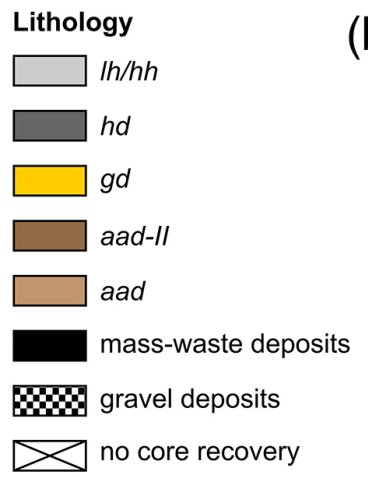

(b) core section lab ID fraction (mm) dry weight (g) dry weight (\%)

\begin{tabular}{|clccrr|}
\hline $\mathbf{5 0 1 7 - 1 - A - 9 0 - 1}$ & DS2 & & & & \\
$\mathbf{4 0 - 4 5} \mathbf{~ c m}$ & DS2-1 & $>4$ & $>$ FGr & 2.014 & 3.54 \\
& DS2-2 & $2-4$ & FGr & 21.012 & 36.92 \\
& DS2-3 & $1-2$ & CSa & 5.102 & 8.96 \\
& DS2-4 & $0.5-1$ & MSa-CSa & 0.169 & 0.30 \\
& DS2-5 & $<0.5$ & $<$ MSa & 28.622 & 50.29 \\
\hline $\mathbf{5 0 1 7 - 1 - A - 9 2 - 1}$ & DS3 & & & & \\
$\mathbf{3 0 - 3 5} \mathbf{c m}$ & DS3-1 & $>4$ & $>$ FGr & 33.640 & 47.82 \\
& DS3-2 & $2-4$ & FGr & 35.110 & 49.91 \\
& DS3-3 & $1-2$ & CSa & 1.556 & 2.21 \\
& DS3-4 & $0.5-1$ & MSa-CSa & 0.045 & 0.06 \\
& DS3-5 & $<0.5$ & $<$ MSa & 0 & 0 \\
\hline
\end{tabular}

Figure 3. (a) Lithological profile from 233 to $242 \mathrm{~m}$ composite depth (cc - core catcher), two gravel deposits in core sections (1) 5017-1A-90-1 (233.17 m composite depth) and (2) 5017-1-A-92-1 (239.27 m composite depth) and strewn thin slide scans (polarised light) of the 2-4 mm grain fractions; yellow bars indicate sampling positions in the two core sections. (b) Table of grain size fractions after sieving for one example of a mud-supported gravel occurrence and the pure gravel layer, both as shown in (a).

(gd facies) revealed the coarsest mean grain size of $\sim 8 \mu \mathrm{m}$ $\left(\sim 12.5 \mu \mathrm{m}\right.$ without $\left.\mathrm{CaCO}_{3}\right)$ and the highest sand fraction ( $\sim 0.5$ and $\sim 2.2 \%$, with and without $\mathrm{CaCO}_{3}$, respectively) due to gypsum which was not removed during sample treatment. The aad-n and aad-II micro-facies show similar and low mean grain sizes of $\sim 6 \mu \mathrm{m}\left(\sim 9 \mu \mathrm{m}\right.$ without $\left.\mathrm{CaCO}_{3}\right)$, while the green aad type exhibits a slightly higher mean value of $\sim 7 \mu \mathrm{m}\left(\sim 11 \mu \mathrm{m}\right.$ without $\left.\mathrm{CaCO}_{3}\right)$. Also, the silt and sand fractions of the green aad type are enhanced in comparison to the other two aad types (see the Supplement).
The differentiation of the laminated micro-facies types gd, aad-II, aad-n and green aad is supported by total organic carbon and calcium carbonate contents (Fig. 2g). The gd facies is characterised by lowest TOC values of $0.25-0.5$ and $\sim 18 \% \mathrm{CaCO}_{3}$, whereas the aad-II facies $(0.35-0.57 \%$ TOC, $\left.30-47 \% \mathrm{CaCO}_{3}\right)$ and the aad-n facies $(0.6-0.7 \%$ TOC, $\sim 47 \% \mathrm{CaCO}_{3}$ ) exhibit higher values. The green aad facies is characterised by highest TOC $(0.65$ and $\sim 0.9 \%)$ and $\mathrm{CaCO}_{3}$ contents $(\sim 40-50$ and $62 \%)$.

The elements $\mathrm{Si}, \mathrm{S}, \mathrm{Cl}, \mathrm{K}, \mathrm{Ca}, \mathrm{Ti}, \mathrm{Fe}, \mathrm{Br}$ and $\mathrm{Sr}$ were obtained by $\mu \mathrm{XRF}$ scanning and used to characterise the Dead 


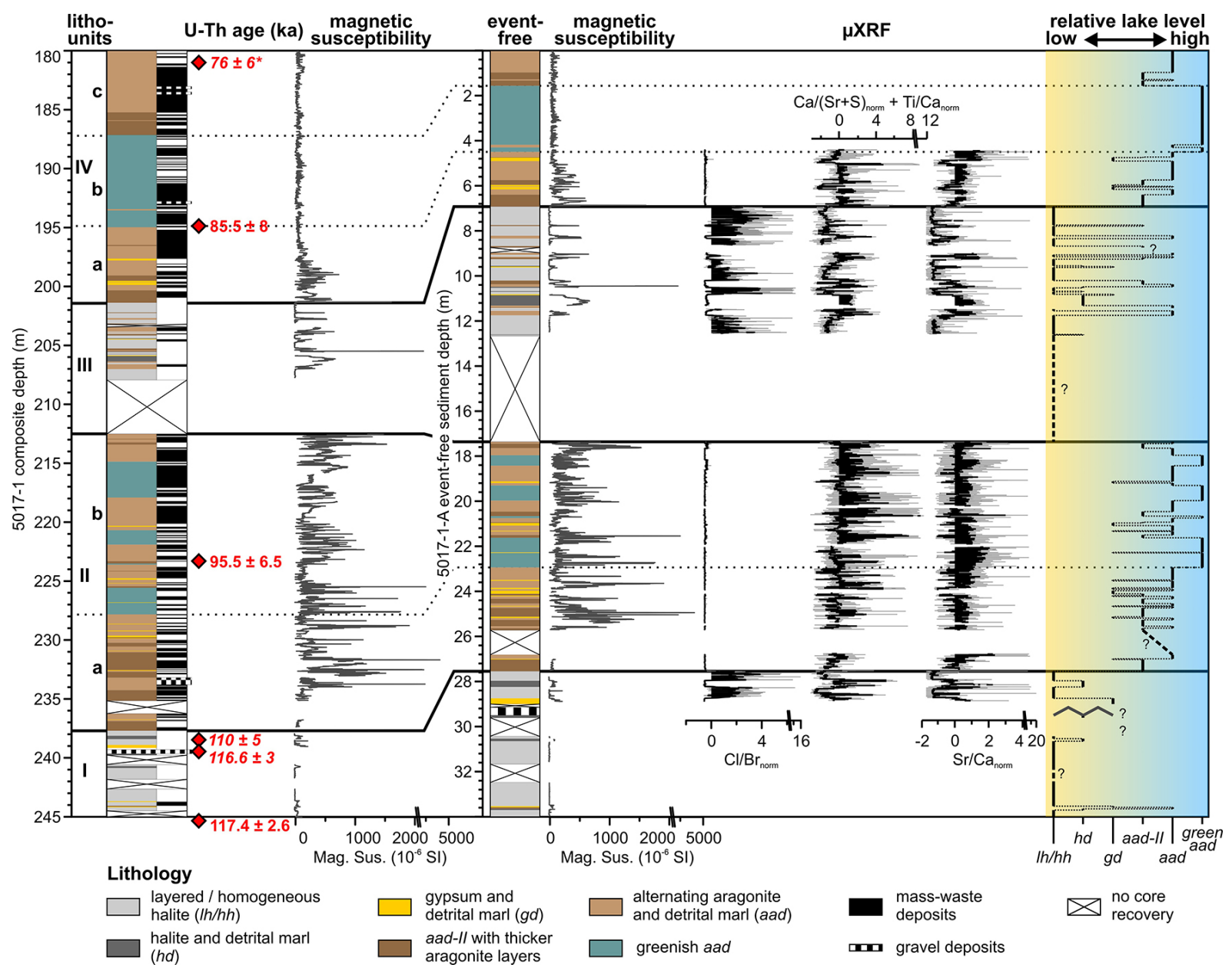

Figure 4. Lithology of the $\sim 65 \mathrm{~m}$ long 5017-1 core section: lithostratigraphic units, U-Th ages (from Torfstein et al., 2015), with extrapolated ages in italic, ${ }^{*}$ - interpolated age (see text for explanation), magnetic susceptibility ( $1 \mathrm{~mm}$ resolution, $10^{-6} \mathrm{SI}$ ); event-free lithology, $\mu$ XRF data (grey: $200 \mu \mathrm{m}$ steps, black: 101-steps running means of counts) and the relative lake level changes inferred from the changing micro-facies. All mass-waste deposits thicker than $1 \mathrm{~cm}$ were excluded from the event-free lithological profile and data; event-free sediment depth starts with zero at $180 \mathrm{~m}$ below lake floor. $\mu \mathrm{XRF}$ data of normalised ratios: $\mathrm{Cl} / \mathrm{Br}$ representing halite, $\mathrm{Ca} /(\mathrm{Sr}+\mathrm{S})+\mathrm{Ti} / \mathrm{Ca}$ indicating the total carbonate and siliciclastic detritus, and $\mathrm{Sr} / \mathrm{Ca}$ indicating aragonite.

Sea sediments (Fig. 2; see also Neugebauer et al., 2014, 2015). Aragonite laminae are revealed by high $\mathrm{Sr} / \mathrm{Ca}$ values, gypsum is represented by high $\mathrm{S} / \mathrm{Ca}$ values and halite is best characterised by the $\mathrm{Cl} / \mathrm{Br}$ ratio (Fig. 2). The elements $\mathrm{Si}, \mathrm{K}, \mathrm{Ti}$ and $\mathrm{Fe}$ are constrained to siliciclastics in the detrital sediment fraction. More ambiguous is the interpretation of $\mathrm{Ca}$ that occurs in aragonite, gypsum and detrital calcite. The $\mathrm{Ca} /(\mathrm{Sr}+\mathrm{S})$ ratio indicates the detrital carbonate fraction because the authigenic $\mathrm{Ca}$ sources, i.e. aragonite and gypsum, are removed. $\mathrm{The} \mathrm{Ti} / \mathrm{Ca}$ ratio represents the relative siliciclastic fraction (Fig. 2). The sum of $\mathrm{Ca} /(\mathrm{Sr}+\mathrm{S})$ and $\mathrm{Ti} / \mathrm{Ca}$ ratios best represents the total amount of carbonate and siliciclastic detritus (Fig. 4). A correlation plot of these two element ratios shows low, but significant, correlation $\left(R^{2}=0.4\right)$ for the carbonate and siliciclastic detrital fractions (Fig. 2h); the plot also indicates an additional Ca-bearing detrital fraction.

\subsection{Lithostratigraphy}

The analysed section of core 5017-1 is subdivided into four main lithostratigraphic units (Fig. 4). Units I and III are predominantly composed of halite (controlled by hd and $\mathrm{lh} / \mathrm{hh}$ facies), some gypsum and detrital marl. Units II and IV present primarily aad (green aad, aad-n and aad-II) and gd facies. These lithostratigraphic units are tied to the stratigraphic framework (Neugebauer et al., 2014) and the U-Th chronology (Torfstein et al., 2015) of the 5017-1 core.

The lowermost unit I (245-237.5 m composite depth) is the upper part of a ca. $40 \mathrm{~m}$ thick halite sequence, the thickest halite deposit in the entire core, and is part of the last interglacial Samra Formation (Neugebauer et al., 2014). This unit 
has very low magnetic susceptibility values and $\mathrm{Sr} / \mathrm{Ca}$ ratios with high $\mathrm{Cl} / \mathrm{Br}$ ratios (Fig. 4). The above-mentioned well-sorted gravel deposit, mainly composed of limestone and dolomite clasts and halite, was identified $\sim 2 \mathrm{~m}$ below the top of this halite unit (Figs. 3 and 4). U-Th ages proposed a sedimentary hiatus between ca. 116 and $110 \pm 3 \mathrm{ka}$ marked by this gravel layer (Torfstein et al., 2015).

The $\sim 25 \mathrm{~m}$ thick unit II (237.5-212.5 m) presents mainly aad and gd facies. It is divided into two subunits: (1) subunit II-a (237.5-228 m) comprises aad-II, aad-n and gd facies and is characterised by low $\mathrm{Sr} / \mathrm{Ca}$ and $\mathrm{Cl} / \mathrm{Br}$ ratios and distinct peaks in magnetic susceptibility. (2) Subunit II-b (228-212.5 m) differs from subunit II-a as, in addition to the above facies, it presents three thick sequences characterised by green aad facies and partly high $\mathrm{Sr} / \mathrm{Ca}$ ratios. Unit II is characterised by frequent, up to several metres thick, graded detrital layers and slump deposits (Fig. 4). U-Th ages place unit II between ca. $108 \pm 5$ and $93 \pm 7 \mathrm{ka}$ (Torfstein et al., 2015 ), i.e. an interval of $\sim 3-27000$ years. Preliminary varve counting on the core photographs of this unit reveals a minimum of $4050 \pm 250$ varves, which is at the lower end of the range and uncertainty of the U-Th ages. It is likely that much of the sediment was eroded through the frequent mass-waste events. Unit II builds the upper part of the Samra Formation of core 5017-1 as defined by Neugebauer et al. (2014).

Unit III $(212.5-201.5 \mathrm{~m})$ is dominated by halite deposits of the hd and $\mathrm{lh} / \mathrm{hh}$ facies, which is well reflected in high $\mathrm{Cl} / \mathrm{Br}$ ratios. The lower ca. $4 \mathrm{~m}$ of this unit could not be recovered due to the hardness of the salt. Some centimetreto decimetre-thick occurrences of aad-n, aad-II and gd facies are intercalated in the halite deposits, as reflected by higher magnetic susceptibility, $\mathrm{Ca} /(\mathrm{Sr}+\mathrm{S})+\mathrm{Ti} / \mathrm{Ca}$ and $\mathrm{Sr} / \mathrm{Ca}$ ratios. Unit III was deposited between ca. 93 and $87 \pm 7 \mathrm{ka}$ (Torfstein et al., 2015) and probably marks the transition between the Samra and Lisan formations in the deep-basin core 5017-1 (Neugebauer et al., 2014). Compared to the chronology of the outcrops at the margin where the Samra-Lisan transition has been traditionally considered at $75-70 \mathrm{ka}$ (e.g. Waldmann et al., 2009), probably because of transgressive truncation, the deep core may indicate that the transition occurred ca. 15000 years earlier (Torfstein et al., 2015).

The uppermost unit IV (201.5-180 m) compares to unit II and is characterised by the three aad facies, as indicated by higher $\mathrm{Ca} /(\mathrm{Sr}+\mathrm{S})+\mathrm{Ti} / \mathrm{Ca}$ and $\mathrm{Sr} / \mathrm{Ca}$ ratios and the absence of halite (Fig. 4). In contrast to unit II, where magnetic susceptibility values strongly fluctuate, constantly low magnetic susceptibility characterises unit IV (Fig. 4). This unit can be divided into three subunits: (1) subunit IV-a is composed of aad-n, aad-II and gd facies; (2) subunit IV-b is a green aad section; and (3) subunit IV-c is composed of aad-n and aad-II. Several centimetre- to metre-thick slumped deposits and graded detrital layers occur in unit IV. At a composite core depth of $\sim 195 \mathrm{~m}$ the sediment is ca. $85.5 \pm 8 \mathrm{ka}$, and $6 \mathrm{~m}$ above unit IV (i.e. at $174.5 \mathrm{~m}$ depth) an age of $70.5 \pm 5 \mathrm{ka}$ has been reported (Torfstein et al., 2015). The interpolated age of the upper boundary of unit IV at $180 \mathrm{~m}$ depth is ca. $75 \pm 6 \mathrm{ka}$. Unit IV builds the lowermost part of the Lisan Formation of core 5017-1 (Neugebauer et al., 2014).

\section{Discussion}

\subsection{Micro-facies as relative lake level indicators}

Lake levels of the water bodies occupying the Dead Sea basin are sensitive responders to changing hydro-climatic conditions in the lake's catchment (Enzel et al., 2003, 2008; Bookman et al., 2006). Lake level reconstructions based on onshore sequences indicate a total amplitude of lake level fluctuation of at least $\sim 270 \mathrm{~m}$, with lowest levels of $\sim 430 \mathrm{mb}$ b.m.s.l. occurring during parts of the last interglacial, the last termination, potentially the Holocene and anthropogenically induced - in modern times (e.g. Bookman (Ken-Tor) et al., 2004; Bartov et al., 2007; Waldmann et al., 2009; Stein et al., 2010). The highest lake level of Lake Lisan of $\sim 160 \mathrm{~m}$ b.m.s.l. was reached during the last glacial maximum (Bartov et al., 2003). These exposed sediments at the Dead Sea margins also showed that in general different lake levels resulted in different sedimentary facies (e.g. Machlus et al., 2000; Migowski et al., 2006). Hence, facies types can be considered relative lake level indicators, but without assigning an absolute level change (Figs. 4 and 5). Unlike the near-shore environment, where lateral changes can alter the sedimentary facies, which may lead to erroneous relative lake level interpretations, in the deep basin such lateral changes are uncommon and, therefore, facies changes are better related to changes in relative lake levels. These relative lake levels are crucial to infer regional, basin-scale hydroclimatic changes that control the direction of lake level trends (i.e. rising or falling), which are the net product of the respective positive or negative lake budget over decades to millennia. To avoid complexities in inferring minor relative lake level changes and to remain reasonable within the resolution of the U-Th chronology, we concentrated only on reconstructing the millennial-scale facies alterations and interpret them in terms of relative lake level variations.

The typical sediment facies during rising levels and the resulting episodic high stands of both the deep last glacial Lake Lisan and the much shallower Holocene Dead Sea is the aad facies composed of alternating aragonite and detritus (e.g. Machlus et al., 2000; Bookman (Ken-Tor) et al., 2004). As the lake is devoid of bicarbonate, deposition of aad requires large amounts of bicarbonate supply by freshwater reaching the lake through runoff during the winter rainy season to trigger precipitation of primary aragonite (Stein et al., 1997; Barkan et al., 2001). Three different subtypes of aad were distinguished in the investigated sediment section through micro-facies analyses. (i) Green aad (Fig. 2) comprises greenish detrital laminae containing green algae remains and represents highest lake levels and less salty lim- 


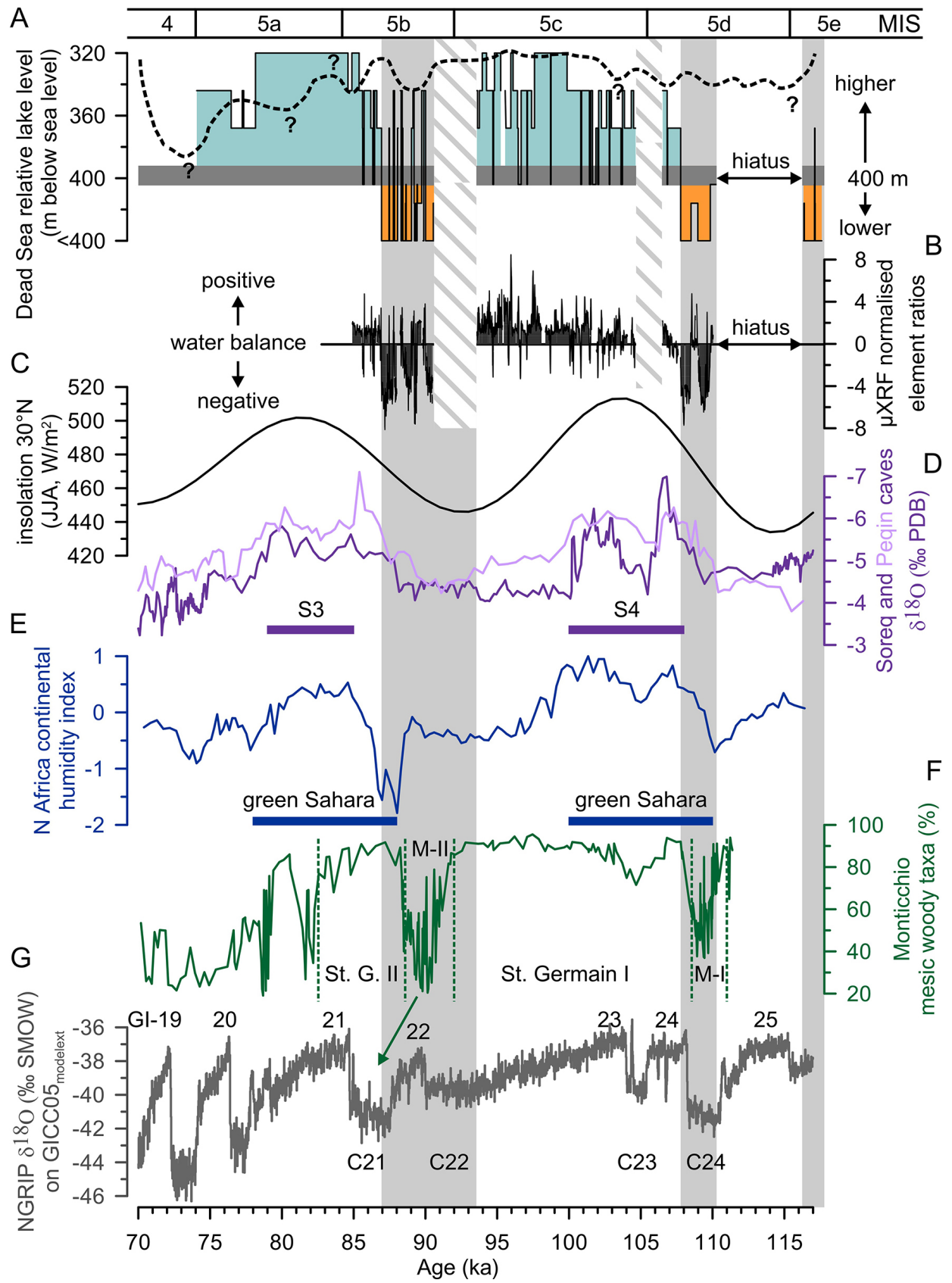

Figure 5. Comparison of the Dead Sea to other records: (a) the relative Dead Sea lake level curve inferred from micro-facies analysis of the deep-basin core 5017-1 (this study; right $y$ axis) and from site PZ-7 from the Perazim Valley (dashed line; left $y$ axis, indicating maximum or minimum relative lake levels; Waldmann et al., 2009); (b) sum of normalised ratios of $\mathrm{Ca} /(\mathrm{Sr}+\mathrm{S})$ and $\mathrm{Ti} / \mathrm{Ca}$ as proxies for carbonate and siliciclastic detritus, respectively, and of $\mathrm{Sr} / \mathrm{Ca}$, proxy for aragonite, subtracted by the $\mathrm{Cl} / \mathrm{Br}$ ratio, which is a proxy for halite, [Ca / $\mathrm{Sr}+\mathrm{S}$ ) $+\mathrm{Ti} / \mathrm{Ca}+\mathrm{Sr} / \mathrm{Ca}-\mathrm{Cl} / \mathrm{Br}$ indicating the water balance of the lake and agreeing well with the relative lake level curve; (c) mean summer (JJA) insolation at $30^{\circ} \mathrm{N}$ (after Laskar et al., 2004); (d) $\delta^{18} \mathrm{O}$ of Soreq and Peqin speleothems, Israel (Bar-Matthews et al., 2003), and eastern Mediterranean sapropel events S3 and S4 (according to Bar-Matthews et al., 2000); (e) humidity index of continental North Africa (core GeoB7920-2) and "green Sahara" phases (Tjallingii et al., 2008); (f) Monticchio (southern Italy) pollen record of mesic woody taxa and Mediterranean pollen zones Melisey (M) I and II, and St. Germain I and II (Brauer et al., 2007; Martin-Puertas et al., 2014) - note a possible chronological shift of 3500 years to the older for 92-76 ka according to Martin-Puertas et al. (2014); (g) Greenland ice core $\delta^{18} \mathrm{O}$ record on GICC05 modelext timescale (Wolff et al., 2010) - also indicated are Greenland interstadials (GI) after Rasmussen et al. (2014) and North Atlantic ice-rafting events C21 to C24 (Chapman and Shackleton, 1999). Marine isotope stages are given according to Wright (2000). Grey vertical bars indicate periods of negative water balance in the Dead Sea; obliquely banded bars: no core recovery. 
nological conditions. This facies depicts the sediments deposited in core 5017-1 during the Last Glacial Maximum high stands (Neugebauer et al., 2014), when Lake Lisan reached its maximum extent (e.g. Begin et al., 1974; Bartov et al., 2002). (ii) The aad-n and (iii) the aad-II facies are similar, except that aad-II is characterised by commonly thicker but irregularly spaced aragonite laminae (Fig. 2). This may indicate insufficient supply of bicarbonate to support regular annual aragonite formation. Therefore, the aad-II facies was likely deposited during episodes of somewhat lower lake levels compared to the aad-n facies. The aad-II facies also differs from the ld facies type (laminated detritus), which exhibits coarser detritus $(50-60 \mu \mathrm{m})$ than aad (8-10 $\mu \mathrm{m}$; HalivaCohen et al., 2012) and which is a characteristic facies for intermediate lake levels of the interglacial Samra and Ze'elim formations (e.g. Migowski et al., 2006; Waldmann et al., 2009; Neugebauer et al., 2014). The ld facies type was, however, not detected in the studied core section, which is supported by the constantly very fine grain sizes of the sediments (Supplement).

The deposition of well-laminated or massive gypsum ( $\mathrm{gd}$ facies, Fig. 2) is associated with mixing of the water body due to lake level fall and a thinning of the upper freshwater layer (Torfstein et al., 2008). Halite deposition is related to a negative water balance during times of decreased lake levels (e.g. Lazar et al., 2014). Here, we distinguish between a mixed halite-detritus facies (hd) and layered or homogeneous, consolidated halite (lh/hh facies, Fig. 2). Whereas the presence of detritus suggests freshwater influx during extreme runoff events, deposition of thick halite indicates episodes of lowest lake levels.

Lake level trends inferred from micro-facies analysis are supported by $\mu \mathrm{XRF}$ element scanning data (Figs. 4 and 5). Halite sequences associated with a negative water balance are well expressed in increased $\mathrm{Cl} / \mathrm{Br}$ ratios. The detrital input depends on the erosion in the catchment, aeolian deposition over the lake and the catchment, and freshwater supply to the lake. The relative detrital input can be estimated using the $\mathrm{Ca} /(\mathrm{Sr}+\mathrm{S})$ ratio (for carbonate fraction) and the $\mathrm{Ti} / \mathrm{Ca}$ ratio (for siliciclastic fraction). $\mathrm{The} \mathrm{Sr} / \mathrm{Ca}$ ratio resembles the aragonite amount that increases with enhanced supply of freshwater. The combination of these ratios by summing up both detrital fractions and aragonite and subtracting halite results in a curve that can be interpreted as a proxy for water balance (Fig. 5), with negative values for halite and gypsum deposits and positive values for detritus and aragonite.

\subsection{Gravel deposits in the deep basin}

Gravel deposits are rather common in the deep basin and have been identified as matrix-supported material mainly in basal layers of turbidites and slumps that are up to several metres thick and reflect mass-waste deposits, which can be triggered by either extreme runoff or seismic events and slope instabilities (Kagan and Marco, 2013; Neugebauer et al.,
2014; Waldmann et al., 2014). Only in one case at $\sim 239 \mathrm{~m}$ composite sediment depth has a $35 \mathrm{~cm}$ thick well-sorted gravel deposit lacking fine-grained components been documented (Figs. 3 and 4). This gravel has been interpreted as beach deposit and in turn used to argue for a major drawdown or even almost desiccation of the lake at the end of the last interglacial (Stein et al., 2011; Torfstein et al., 2015). Combined U-Th ages and oxygen isotope stratigraphy suggest a $\sim 116$ to $110 \mathrm{ka}$ hiatus at around the position of the gravel deposit, which is assumed to support the drawdown hypothesis (Torfstein et al., 2015). However, both petrographic composition and grain characteristics of the well-sorted gravel are identical to gravel in basal layers of thick slumps and turbidites as the one deposited only $6 \mathrm{~m}$ above (at $\sim 233 \mathrm{~m}$ composite sediment depth; Fig. 3). This suggests the possibility of a similar source and even the same transport mechanism. Due to the massive core loss of $65 \%$ in the core section where the well-sorted gravel was found, no direct information about the in situ contacts of this gravel to overand underlying sediment units is available (Fig. 3a) and its primary sedimentological context remains unknown. However, the core catcher material supports the interpretation of even the well-sorted gravel as the vestige of a major masswaste deposit, since it consists of matrix-supported gravel exactly resembling basal layers from at least 22 turbidites and slumps occurring in the entire record. It is likely that the fine-grained sediment components of the turbidite were washed out during the drilling process. Low core recoveries and loss of material often occurred in sediment sections with alternating hard halite and soft mud (Neugebauer et al., 2014) as in this section of the record above the major halite deposit. Therefore, we are convinced that the well-sorted gravels are the result of a drilling artefact and should not be interpreted as an in situ beach layer but rather as the washed-out relict of the basal sediments of a major mass-waste deposit. The deposition of a thick turbidite could have also caused the supposed hiatus, although its length should be critically tested.

Accepting our reinterpretation of the well-sorted gravel as primarily a drilling relict of a turbidite instead of an in situ beach deposit implies that the Dead Sea was not necessarily desiccated at the end of the last interglacial, although it might have been at a low stage. This consideration accords better with thermodynamic calculations and water balance simulations concluding that the chemistry of the brine and the geometry of the basin should prevent the lake from drying up (Yechieli et al., 1998; Krumgalz et al., 2000). First, the specific chemical composition of the Dead Sea brine (mainly $\mathrm{Mg}, \mathrm{Na}, \mathrm{Ca}$ and $\mathrm{Cl}$ ) allows for a very high salinity with a low water activity and vapour pressure to be reached. Therefore, the rate of evaporation decreases with increasing salinity. Second, the low surface-area-to-volume ratio of the lake basin limits the amount of evaporated water. In addition, the relative humidity of the air above the brine has to be close to zero in order to further evaporate a highly concentrated brine, which, however, was never observed (Katz and Starin- 
sky, 2015) and is considered unlikely, especially at very low lake levels, due to the wind-protected topography of the deep Dead Sea basin.

\subsection{Relative lake level fluctuations between $\sim 117$ and $75 \mathrm{ka}$}

Relative lake levels have been reconstructed for the $\sim 117$ $75 \mathrm{ka}$ interval based on the six micro-facies types introduced above (Figs. 4 and 5). Relatively lower lake levels are reflected by the halite-dominated units I $(\sim 117-108 \mathrm{ka})$ and III ( $~ 93-87 \mathrm{ka})$. Intermediate to relatively higher lake levels are inferred for the aad facies-dominated units II ( 108-93 ka) and IV $(\sim 87-75 \mathrm{ka})$ because this facies indicates increased fresh water inflow.

The age estimate of unit I indicates that the low stand of Lake Samra commenced during the later part of the last interglacial and may have continued until $\sim 108 \pm 5 \mathrm{ka}$ (Fig. 5). However, there is no information for the time interval from $\sim 116$ to $110 \pm 4 \mathrm{ka}$, due to the erosional unconformity revealed from the chronological data (Torfstein et al., 2015). The deposition of ca. $2 \mathrm{~m}$ of halite above the hiatus indicates that low levels of the lake continued until $\sim 108 \pm 5 \mathrm{ka}$ because, for times of halite deposition in the Dead Sea basin, a lake level below $400 \mathrm{~m}$ b.m.s.l. can be assumed (Neev and Emery, 1967; Bookman (Ken-Tor) et al., 2004; Waldmann et al., 2009; Stein et al., 2010).

During $\sim 108-93 \pm 6 \mathrm{ka}$ (unit II) a trend of general increase in lake level is indicated by the succession from aad-II to aad-n and finally to the green aad facies (Fig. 4). Intercalated gypsum deposits from $\sim 108$ to $100 \mathrm{ka}$ indicate frequent short-term drops in lake levels. In the last glacial Lisan Formation such gypsum deposits were associated with reduced precipitation, intensified winds and probably increased evaporation during Heinrich events (Bartov et al., 2003; Torfstein et al., 2008, 2013; Rohling, 2013). A Lake Samra highstand between $\sim 100$ and $93 \mathrm{ka}$ is in agreement with a level from exposures at the lake's margins, where a relatively high level of $\sim 320 \mathrm{~m}$ b.m.s.l. was proposed (Fig. 5; Waldmann et al., 2009, 2010).

An abrupt lake level decline and a subsequent millennialscale low stand, probably below $400 \mathrm{~m}$ b.m.s.l., is inferred from the $\sim 7 \mathrm{~m}$ thick halite deposit during the $\sim 93$ $87 \pm 7 \mathrm{ka}$ interval (unit III, Figs. 4 and 5). Within this unit some aad-n, aad-II and gd facies alternate with the thick and mainly layered halite deposits indicating superimposed, probably centennial-scale, lake level fluctuations. This halite sequence represents the final stage of the Samra Formation and marks the last appearance of halite for the next $\sim 70000$ years (Neugebauer et al., 2014) until the early Holocene salt formation (e.g. Yechieli et al., 1993; Stein et al., 2010). The late Lake Samra halite indicates a more pronounced lake level drop than the limited lake level decline inferred from coarser clastic deposits in the exposed lake margin sediments (Fig. 5; Waldmann et al., 2009).
During $\sim 87-79 \pm 7 \mathrm{ka}$ (units IV-a and IV-b) lake level increased again as evidenced from the succession from aadII and aad-n facies, intercalated by some gd facies, to green aad facies (Fig. 4). At $\sim 79 \mathrm{ka}$ (unit IV-c) the lake probably shortly declined again as indicated by aad-II facies, before continuing to rise again at $\sim 77 \pm 6 \mathrm{ka}$ (Fig. 5). Earlier studies of the exposed sediments of the Samra and Lisan formations suggested that a depositional unconformity between $\sim 75$ and 70 ka separated these two formations at the lake's margins (Bartov et al., 2003; Waldmann et al., 2009; Torfstein et al., 2013). Above this assumed unconformity, aad facies characterise the lower and upper members of the Lisan Formation (e.g. Bartov et al., 2002). Below the unconformity, the onshore Samra Formation is composed of reddish ld facies, sands and gravels (Waldmann et al., 2009). In the deep core, however, there is no obvious sedimentological indication for a low stand of the lake at around this time, but aad facies apparently continuously deposited since $\sim 87 \mathrm{ka}$. This suggests that Lake Lisan commenced ca. 10-15 kyr earlier than was assumed from the exposures where its deposits were in part truncated. This difference between shallow- and deepbasin sediments might be explained by (1) the abundant occurrence of slumping deposits and graded layers in the deep core (Fig. 4) or (2) by a lake level rise from a lower level to the level of the observed unconformity at the margins during that time. Combining these two possibilities suggests that these slumping deposits might indicate transgressive erosion at the outcrop locations during times of lake level rise of the early Lake Lisan (Bartov et al., 2007). This is likely causing unconformities in the near-shore marginal areas of the basin. The large number of slump deposits within this sediment section might point to several short-term level oscillations during this generally rising level trend, but there is no further evidence for this proposition.

\subsection{Hydroclimatic implications}

The Dead Sea is situated at a key transitional zone between predominantly Atlantic and tropical-influenced climates. The zone of interaction between both climate regimes is expected to have changed during major climatic transitions like from glacial to interglacial modes and vice versa. In contrast to the scarce and sometimes contradicting information from the Levant, several records from the entire Mediterranean realm provide evidence for teleconnections of large-scale climate variations with the North Atlantic climate regime during the early last glacial. The alternation of cold stadial intervals from $\sim 111$ to $108 \mathrm{ka}$ (GS 25$)$ and $\sim 90$ to $85 \mathrm{ka}(\mathrm{GS} 23+22$; Rasmussen et al., 2014), as reflected in Greenland ice cores (Fig. 5; Wolff et al., 2010) and North Atlantic ice-rafting events C24 and C22+C21 (Chapman and Shackleton, 1999), and warmer interstadials (GI 24+23 and GI 21; Rasmussen et al., 2014) are well expressed in the western (marine core MD952042 off the Iberian margin; Sánchez Goñi et al., 1999), central (Lago Grande di Monticchio; Fig. 5; Brauer et 
al., 2007; Martin-Puertas et al., 2014) and eastern Mediterranean (Tenaghi Philippon: Tzedakis, 2005; Lake Van: Litt et al., 2014; and marine sediments: Cheddadi and RossignolStrick, 1995). The same pattern of large-scale fluctuations is proposed from Lebanon (Lake Yammoûneh; Develle et al., 2011; Gasse et al., 2015) and the Soreq and Peqin speleothem records in Israel (Fig. 5; Bar-Matthews et al., 1999, 2000, 2003). Finally, the Dead Sea record also reveals low water levels at $\sim 110-108 \pm 5$ and $\sim 93-87 \pm 7 \mathrm{ka}$, reflecting dry periods corresponding to Northern Hemisphere stadials, and higher lake levels at $\sim 108-93 \pm 6$ and $\sim 87-75 \pm 6$ ka coinciding with Greenland interstadials (Fig. 5).

The long interstadials interrupted by short stadials in the North Atlantic realm during the build-up phase of the large continental ice sheets (e.g. Mangerud et al., 1996, 1998; Clark et al., 1999; Svendsen et al., 2004) are related to changes in Northern Hemisphere orbital insolation (Fig. 5; Laskar et al., 2004). At the same time, orbital insolationdriven changes of the Intertropical Convergence Zone controlled the monsoon system and led to a strengthening of the African summer monsoon and widespread vegetation cover in the Sahel and in the southern Sahara regions (Fig. 5; deMenocal et al., 2000; Tjallingii et al., 2008; Herold and Lohmann, 2009). Enhanced precipitation in eastern Africa induced the formation of organic-rich sapropel layers S4 and S3 (Fig. 5) in the eastern Mediterranean Basin due to enhanced Nile River runoff (e.g. Rossignol-Strick, 1985; Rohling et al., 2015). These changes in freshwater flow further influenced the isotopic composition of the eastern Mediterranean Sea water, i.e. the source region for precipitation in the region of the Soreq and Peqin speleothems (Fig. 5; Bar-Matthews et al., 2000, 2003). This is an indirect mechanism explaining a monsoonal influence in the speleothem records of the Levant.

Two issues must be discussed when precipitation increase and decrease are considered for explaining rising and falling trends in lake levels and their maxima: (a) winter vs. summer precipitation, and (b) tropical vs. Atlantic-Mediterranean sources. Different scenarios have been proposed but the source of moisture for the precipitation leading to higher Dead Sea lake levels during the early glacial and related atmospheric teleconnections is still debated. Northward shifts of the tropical rain belt as far north as the Levant have been excluded (Tzedakis, 2007, and references therein), and Enzel et al. (2015) also argued that summer rains associated with either the African or Indian monsoons are unlikely even in the southernmost point of the Dead Sea watershed. Based on hyperarid soils, Amit et al. $(2006,2011)$ demonstrated that the southern Negev, including the southern watershed of the Dead Sea, has been hyperarid since the early Pleistocene. This is further supported by a diminishing speleothem growth southward and a proposal for a predominating Atlantic-Mediterranean source of winter precipitation in the Negev during relatively short episodes of the last interglacial (Vaks et al., 2010). This apparently contra- dicts the hypothesis that a northward shift of summer rains from monsoonal sources to the southern Levant contributed to the slightly increased Dead Sea lake level during the early last glacial (Torfstein et al., 2015). Less attention has been paid to seasonal shifts in precipitation as a factor for lake level fluctuations. One reason is that most model studies focus on the summer season (e.g. Liu et al., 2004; Herold and Lohmann, 2009), while information about the winter season atmospheric circulation during intervals of maximum insolation is still scarce. One exception is the study by Kutzbach et al. (2014), which suggests that an increase in winter storm tracks could have caused the wetter intervals in the Levant during maximum Northern Hemisphere seasonality.

Present-day observations identified a third possible mechanism of moisture supply to the southern Levant. Winter to spring tropical plumes originating from the tropical eastern Atlantic and western Africa usually transport moisture across the Sahara into the southern Levant deserts when the subtropical jet is at a southern latitudinal position (e.g. Kahana et al., 2002; Rubin et al., 2007; Tubi and Dayan, 2014). Increasing the frequencies of such atmospheric circulation patterns that cause widespread ample rainstorms is probably the only way to increase the runoff yield in southern Negev drainage basins (e.g. Enzel et al., 2012) to a volume that will be noticed as a level change, although minor, in the Dead Sea. Low-latitude tropical plumes have been also proposed as a moisture source in the past when Northern Hemisphere insolation reached maxima during times of the last interglacial Lake Samra (Waldmann et al., 2009, 2010).

Disentangling the interactions of low-latitude/tropical and mid-latitude (Atlantic and Mediterranean) moisture sources and related mechanisms that triggered the reconstructed long-term and large-scale lake level fluctuations of the Dead Sea during the first 40 millennia of the last glacial is challenging and remains partly speculative. One reason for this difficulty might be that orbital-driven changes in insolation and seasonality are the common external trigger for both high- and low-latitude climatic fluctuations during that time. Nevertheless, the striking coincidence with palaeoclimatic records across the Mediterranean suggests a strong role of the Atlantic-Mediterranean atmospheric circulation for the moisture supply to the Levant during the last glacial inception.

The observed coincidence of a cold North Atlantic and dry southern Levant during the last glacial inception is apparently in contradiction with the long-term observations of glacial high stands and interglacial low stands at the Dead Sea. This apparent difference in the Dead Sea lake level response to North Atlantic climate changes at different timescales might be explained by threshold effects in the growth of the Fennoscandian ice sheet. Once the ice shield reached a certain height, it became a morphological barrier causing a major system shift in the atmospheric circulation pattern (Webb III et al., 1993) which, in turn, forced the Mediterranean storm tracks to shift southward and be fun- 
nelled and intensified towards the central Levant. This would explain the proposed doubling of annual rainfall in this region (Enzel et al., 2003, 2008) and the high Lake Lisan levels during the last glacial (Rohling, 2013). During the glacial inception, different atmospheric boundary conditions prevailed, likely because the ice shield elevation was still below the threshold, which forces the large-scale circulation pattern to change. To test this hypothesis, more high-resolution proxy records from the southern Levant and advanced modelling studies are needed.

\section{Conclusions}

Investigation of a $\sim 65 \mathrm{~m}$ long sediment section of the 50171 core from the deep Dead Sea basin confirmed the sensitivity of sediment deposition to lake level variations. Therefore, micro-facies is a suitable proxy for relative lake level variations and water balance allowing for changing hydroclimatic conditions to be traced in the southern Levant during the early last glacial from $\sim 117$ to $75 \mathrm{ka}$.

Matrix-supported gravel deposits are more common in the deepest part of the Dead Sea basin than previously documented. They are probably transported by mass-waste events during major lake level fluctuations. We propose that the appearance of one well-sorted gravel deposit, which was previously suggested as an in situ beach deposit, is likely an artefact of the drilling process and that this gravel was originally deposited by mass-wasting as well. Therefore, we conclude that there is, at this time, no proof for an almost complete drying of the Dead Sea at the end of the last interglacial.

We suggest that the first phase of an early Lake Lisan commenced ca. $15 \mathrm{kyr}$ earlier than was suggested from the main sedimentological shift in exposed sediments at the lake's margins at $\sim 75-70 \mathrm{ka}$. In the deep basin, Lisan-type sediments, i.e. aad, have been deposited since as early as $\sim 108$ $93 \mathrm{ka}$, but again interrupted by a final period of halite deposition marking the end of Lake Samra at $\sim 87 \mathrm{ka}$.

Large-scale lake level fluctuations of the Dead Sea during the early last glacial (MIS 5d-5a) are in concert with Mediterranean records and climate conditions in the North Atlantic. This suggests that the insolation-driven AtlanticMediterranean cyclone activity and seasonality changes are the main cause of the observed lower lake levels during colder intervals. On longer timescales, this pattern changed and highest lake levels during the Lake Lisan phase occurred during the cold Pleniglacial (MIS 4-2). This might be related to a southward shift and intensification of Mediterranean cyclones towards the Levant due to a shift in atmospheric circulation boundary conditions caused by the growth of Northern Hemisphere ice sheets.

\section{The Supplement related to this article is available online at doi:10.5194/cp-12-75-2016-supplement.}

Acknowledgements. We would like to thank the editor and the two anonymous reviewers for their constructive comments, which helped to improve the quality of the manuscript. Funding by the International Continental Scientific Drilling Program (ICDP), the German Science Foundation (DFG grants FR 1672/2-1 and BR 2208/10-1), the GFZ German Research Centre for Geosciences and the Israel Science Foundation (ISF) Dead Sea Core-Center of Excellence Research (grant no. 1436/14 to Y. Enzel) is gratefully acknowledged. A. Agnon was supported by the DESERVE Helmholtz Virtual Institute. We thank G. Arnold, D. Berger and B. Brademann for preparing excellent thin sections and for technical support; P. Dulski and F. Ott for help with $\mu$ XRF; B. Plessen and $\mathrm{P}$. Meier for TOC and $\mathrm{CaCO}_{3}$ measurements; J. Mingram for support with the fluorescence microscope; G. Schlolaut (all GFZ German Research Centre for Geosciences) and K. Schorling (HU Berlin) for grain size sampling; S. Baltruschat (TU Darmstadt) for assistance with XRD samples; and all people involved in the drilling, core opening and sampling campaigns of the Dead Sea Deep Drilling Project. This study is a contribution to the Helmholtz Association (HGF) climate initiative REKLIM Topic 8 "Rapid climate change derived from proxy data".

The article processing charges for this open-access

publication were covered by a Research

Centre of the Helmholtz Association.

Edited by: L. Skinner

\section{References}

Almogi-Labin, A., Bar-Matthews, M., Shriki, D., Kolosovsky, E., Paterne, M., Schilman, B., Ayalon, A., Aizenshtat, Z., and Matthews, A.: Climatic variability during the last $\sim 90 \mathrm{ka}$ of the southern and northern Levantine Basin as evident from marine records and speleothems, Quaternary Sci. Rev., 28, 2882-2896, doi:10.1016/j.quascirev.2009.07.017, 2009.

Amit, R., Enzel, Y., and Sharon, D.: Permanent Quaternary hyperaridity in the Negev, Israel, resulting from regional tectonics blocking Mediterranean frontal systems, Geology, 34, 509-512, doi:10.1130/g22354.1, 2006.

Amit, R., Simhai, O., Ayalon, A., Enzel, Y., Matmon, A., Crouvi, O., Porat, N., and McDonald, E.: Transition from arid to hyperarid environment in the southern Levant deserts as recorded by early Pleistocene cummulic Aridisols, Quaternary Sci. Rev., 30, 312-323, doi:10.1016/j.quascirev.2010.11.007, 2011.

Barkan, E., Luz, B., and Lazar, B.: Dynamics of the carbon dioxide system in the Dead Sea, Geochim. Cosmochim. Ac., 65, 355368, doi:10.1016/S0016-7037(00)00540-8, 2001.

Bar-Matthews, M., Ayalon, A., Kaufman, A., and Wasserburg, G. J.: The Eastern Mediterranean paleoclimate as a reflection of regional events: Soreq cave, Israel, Earth Planet. Sci. Lett., 166, 85-95, doi:10.1016/s0012-821x(98)00275-1, 1999.

Bar-Matthews, M., Ayalon, A., and Kaufman, A.: Timing and hydrological conditions of Sapropel events in the Eastern Mediterranean, as evident from speleothems, Soreq cave, Israel, Chem. Geol., 169, 145-156, doi:10.1016/S0009-2541(99)00232-6, 2000.

Bar-Matthews, M., Ayalon, A., Gilmour, M., Matthews, A., and Hawkesworth, C. J.: Sea-land oxygen isotopic relationships 
from planktonic foraminifera and speleothems in the Eastern Mediterranean region and their implication for paleorainfall during interglacial intervals, Geochim. Cosmochim. Ac., 67, 31813199, doi:10.1016/S0016-7037(02)01031-1, 2003.

Bartov, Y., Stein, M., Enzel, Y., Agnon, A., and Reches, Z.: Lake Levels and Sequence Stratigraphy of Lake Lisan, the Late Pleistocene Precursor of the Dead Sea, Quaternary Res., 57, 9-21, doi:10.1006/qres.2001.2284, 2002.

Bartov, Y., Goldstein, S. L., Stein, M., and Enzel, Y.: Catastrophic arid episodes in the Eastern Mediterranean linked with the North Atlantic Heinrich events, Geology, 31, 439-442, doi:10.1130/0091-7613(2003)031<0439:caeite> 2.0.co;2, 2003.

Bartov, Y., Enzel, Y., Porat, N., and Stein, M.: Evolution of the Late Pleistocene-Holocene Dead Sea Basin from Sequence Statigraphy of Fan Deltas and Lake-Level Reconstruction, J. Sediment. Res., 77, 680-692, doi:10.2110/jsr.2007.070, 2007.

Begin, Z. B., Ehrlich, A., and Nathan, Y.: Lake Lisan - The Pleistocene precursor of the Dead Sea, Geological Survey of Israel Bulletin, 63 pp., 1974.

Bentor, Y. K.: Some geochemical aspects of the Dead Sea and the question of its age, Geochim. Cosmochim. Ac., 25, 239-260, doi:10.1016/0016-7037(61)90061-8, 1961.

Bookman (Ken-Tor), R., Enzel, Y., Agnon, A., and Stein, M.: Late Holocene lake levels of the Dead Sea, Geol. Soc. Am. Bull., 116, 555-571, doi:10.1130/b25286.1, 2004.

Bookman, R., Bartov, Y., Enzel, Y., and Stein, M.: Quaternary lake levels in the Dead Sea basin: Two centuries of research, Geological Society of America Special Papers, 401, 155-170, doi:10.1130/2006.2401(10), 2006.

Brauer, A., Endres, C., and Negendank, J. F. W.: Lateglacial calendar year chronology based on annually laminated sediments from Lake Meerfelder Maar, Germany, Quatern. Int., 61, 17-25, doi:10.1016/S1040-6182(99)00014-2, 1999.

Brauer, A., Allen, J. R. M., Mingram, J., Dulski, P., Wulf, S., and Huntley, B.: Evidence for last interglacial chronology and environmental change from Southern Europe, P. Natl. Acad. Sci. USA, 104, 450-455, doi:10.1073/pnas.0603321104, 2007.

Chapman, M. R. and Shackleton, N. J.: Global ice-volume fluctuations, North Atlantic ice-rafting events, and deep-ocean circulation changes between 130 and $70 \mathrm{ka}$, Geology, 27, 795798, doi:10.1130/0091-7613(1999)027<0795:givfna> 2.3.co;2, 1999.

Cheddadi, R. and Rossignol-Strick, M.: Eastern Mediterranean Quaternary paleoclimates from pollen and isotope records of marine cores in the Nile Cone Area, Paleoceanography, 10, 291300, doi:10.1029/94pa02672, 1995.

Clark, P. U., Alley, R. B., and Pollard, D.: Northern Hemisphere Ice-Sheet Influences on Global Climate Change, Science, 286, 1104-1111, doi:10.1126/science.286.5442.1104, 1999.

deMenocal, P., Ortiz, J., Guilderson, T., Adkins, J., Sarnthein, M., Baker, L., and Yarusinsky, M.: Abrupt onset and termination of the African Humid Period: rapid climate responses to gradual insolation forcing, Quaternary Sci. Rev., 19, 347-361, doi:10.1016/S0277-3791(99)00081-5, 2000.

Develle, A. L., Gasse, F., Vidal, L., Williamson, D., Demory, F., Van Campo, E., Ghaleb, B., and Thouveny, N.: A $250 \mathrm{ka}$ sedimentary record from a small karstic lake in the Northern Levant (Yammoûneh, Lebanon): Paleocli- matic implications, Palaeogeogr. Palaeoecol. 305, 10-27, doi:10.1016/j.palaeo.2011.02.008, 2011.

Enzel, Y., Bookman, R., Sharon, D., Gvirtzman, H., Dayan, U., Ziv, B., and Stein, M.: Late Holocene climates of the Near East deduced from Dead Sea level variations and modern regional winter rainfall, Quaternary Res., 60, 263-273, doi:10.1016/j.yqres.2003.07.011, 2003.

Enzel, Y., Amit, R., Dayan, U., Crouvi, O., Kahana, R., Ziv, B., and Sharon, D.: The climatic and physiographic controls of the eastern Mediterranean over the late Pleistocene climates in the southern Levant and its neighboring deserts, Global Planet. Change, 60, 165-192, doi:10.1016/j.gloplacha.2007.02.003, 2008.

Enzel, Y., Amit, R., Grodek, T., Ayalon, A., Lekach, J., Porat, N., Bierman, P., Blum, J. D., and Erel, Y.: Late Quaternary weathering, erosion, and deposition in Nahal Yael, Israel: An "impact of climatic change on an arid watershed"?, Geol. Soc. Am. Bull., 124, 705-722, doi:10.1130/b30538.1, 2012.

Enzel, Y., Kushnir, Y., and Quade, J.: The middle Holocene climatic records from Arabia: Reassessing lacustrine environments, shift of ITCZ in Arabian Sea, and impacts of the southwest Indian and African monsoons, Global Planet. Change, 129, 69-91, doi:10.1016/j.gloplacha.2015.03.004, 2015

Gasse, F., Vidal, L., Van Campo, E., Demory, F., Develle, A.-L., Tachikawa, K., Elias, A., Bard, E., Garcia, M., Sonzogni, C., and Thouveny, N.: Hydroclimatic changes in northern Levant over the past 400000 years, Quaternary Sci. Rev., 111, 1-8, doi:10.1016/j.quascirev.2014.12.019, 2015.

Haliva-Cohen, A., Stein, M., Goldstein, S. L., Sandler, A., and Starinsky, A.: Sources and transport routes of fine detritus material to the Late Quaternary Dead Sea basin, Quaternary Sci. Rev., 50, 55-70, doi:10.1016/j.quascirev.2012.06.014, 2012.

Herold, M. and Lohmann, G.: Eemian tropical and subtropical African moisture transport: an isotope modelling study, Clim. Dyn., 33, 1075-1088, doi:10.1007/s00382-008-0515-2, 2009.

Kagan, E. J. and Marco, S.: Seismically triggered mass movement events from the Dead Sea depocentre, International Workshop "Tectonics of the Levant fault and Northern Red Sea", IPG Paris, 2013.

Kahana, R., Ziv, B., Enzel, Y., and Dayan, U.: Synoptic climatology of major floods in the Negev Desert, Israel, Int. J. Climatol., 22, 867-882, doi:10.1002/joc.766, 2002.

Katz, A., Kolodny, Y., and Nissenbaum, A.: The geochemical evolution of the Pleistocene Lake Lisan-Dead Sea system, Geochim. Cosmochim. Ac., 41, 1609-1626, doi:10.1016/00167037(77)90172-7, 1977.

Katz, A. and Starinsky, A.: No drawdown and no hyperaridity in the ancient Dead Sea: (Comments to Torfstein's et al. (2015) paper, EPSL 412, 235-244), Earth Planet. Sci. Lett., 427, 303-305, doi:10.1016/j.eps1.2015.07.006, 2015.

Krumgalz, B. S., Hecht, A., Starinsky, A., and Katz, A.: Thermodynamic constraints on Dead Sea evaporation: can the Dead Sea dry up?, Chem. Geol., 165, 1-11, doi:10.1016/S00092541(99)00156-4, 2000.

Kutzbach, J. E., Chen, G., Cheng, H., Edwards, R. L., and Liu, Z.: Potential role of winter rainfall in explaining increased moisture in the Mediterranean and Middle East during periods of maximum orbitally-forced insolation seasonality, Clim. Dyn., 42, 1079-1095, doi:10.1007/s00382-013-1692-1, 2014. 
Laskar, J., Robutel, P., Joutel, F., Gastineau, M., Correia, A. C. M., and Levrard, B.: A long-term numerical solution for the insolation quantities of the Earth, Astronom. Astrophys., 428, 261285, 2004.

Lazar, B., Sivan, O., Yechieli, Y., Levy, E. J., Antler, G., Gavrieli, I., and Stein, M.: Long-term freshening of the Dead Sea brine revealed by porewater $\mathrm{Cl}^{-}$and $\delta^{18} \mathrm{O}$ in ICDP Dead Sea deep-drill, Earth Planet. Sci. Lett., 400, 94-101, doi:10.1016/j.epsl.2014.03.019, 2014.

Lensky, N. G., Dvorkin, Y., Lyakhovsky, V., Gertman, I., and Gavrieli, I.: Water, salt, and energy balances of the Dead Sea, Water Resour. Res., 41, W12418, doi:10.1029/2005wr004084, 2005.

Litt, T., Pickarski, N., Heumann, G., Stockhecke, M., and Tzedakis, P. C.: A 600,000 year long continental pollen record from Lake Van, eastern Anatolia (Turkey), Quaternary Sci. Rev., 104, 3041, doi:10.1016/j.quascirev.2014.03.017, 2014.

Liu, Z., Harrison, S. P., Kutzbach, J., and Otto-Bliesner, B.: Global monsoons in the mid-Holocene and oceanic feedback, Clim. Dyn., 22, 157-182, doi:10.1007/s00382-003-0372-y, 2004.

Machlus, M., Enzel, Y., Goldstein, S. L., Marco, S., and Stein, M.: Reconstructing low levels of Lake Lisan by correlating fandelta and lacustrine deposits, Quatern. Int., 73-74, 137-144, doi:10.1016/s1040-6182(00)00070-7, 2000.

Mangerud, J., Jansen, E., and Landvik, J. Y.: Late Cenozoic history of the Scandinavian and Barents Sea ice sheets, Global Planet. Change, 12, 11-26, doi:10.1016/0921-8181(95)00009-7, 1996.

Mangerud, J., Dokken, T., Hebbeln, D., Heggen, B., Ingólfsson, Ó., Landvik, J. Y., Mejdahl, V., Svendsen, J. I., and Vorren, T. O.: Fluctuations of the Svalbard-Barents Sea ice sheet during the last 150000 years, Quaternary Sci. Rev., 17, 11-42, doi:10.1016/S0277-3791(97)00069-3, 1998.

Martin-Puertas, C., Brauer, A., Wulf, S., Ott, F., Lauterbach, S., and Dulski, P.: Annual proxy data from Lago Grande di Monticchio (southern Italy) between 76 and $112 \mathrm{ka}$ : new chronological constraints and insights on abrupt climatic oscillations, Clim. Past, 10, 2099-2114, doi:10.5194/cp-10-2099-2014, 2014.

Migowski, C., Stein, M., Prasad, S., Negendank, J. F. W., and Agnon, A.: Holocene climate variability and cultural evolution in the Near East from the Dead Sea sedimentary record, Quaternary Res., 66, 421-431, doi:10.1016/j.yqres.2006.06.010, 2006.

Neev, D. and Emery, K. O. (Eds.): The Dead Sea: Depositional processes and environments of evaporites, Geological Survey of Israel Bulletin, 41, 147 pp., 1967.

Neugebauer, I., Brauer, A., Schwab, M. J., Waldmann, N. D., Enzel, Y., Kitagawa, H., Torfstein, A., Frank, U., Dulski, P., Agnon, A., Ariztegui, D., Ben-Avraham, Z., Goldstein, S. L., Stein, M., and DSDDP Scientific Party: Lithology of the long sediment record recovered by the ICDP Dead Sea Deep Drilling Project (DSDDP), Quaternary Sci. Rev., 102, 149-165, doi:10.1016/j.quascirev.2014.08.013, 2014.

Neugebauer, I., Brauer, A., Schwab, M. J., Dulski, P., Frank, U., Hadzhiivanova, E., Kitagawa, H., Litt, T., Schiebel, V., Taha, N., Waldmann, N. D., and DSDDP Scientific Party: Evidences for centennial dry periods at $\sim 3300$ and $\sim 2800$ cal. yr BP from micro-facies analyses of the Dead Sea sediments, Holocene, 25, 1358-1371, doi:10.1177/0959683615584208, 2015.

Rasmussen, S. O., Bigler, M., Blockley, S. P., Blunier, T., Buchardt, S. L., Clausen, H. B., Cvijanovic, I., Dahl-Jensen, D., Johnsen,
S. J., Fischer, H., Gkinis, V., Guillevic, M., Hoek, W. Z., Lowe, J. J., Pedro, J. B., Popp, T., Seierstad, I. K., Steffensen, J. P., Svensson, A. M., Vallelonga, P., Vinther, B. M., Walker, M. J. C., Wheatley, J. J., and Winstrup, M.: A stratigraphic framework for abrupt climatic changes during the Last Glacial period based on three synchronized Greenland ice-core records: refining and extending the INTIMATE event stratigraphy, Quaternary Sci. Rev., 106, 14-28, doi:10.1016/j.quascirev.2014.09.007, 2014.

Rohling, E. J.: Quantitative assessment of glacial fluctuations in the level of Lake Lisan, Dead Sea rift, Quaternary Sci. Rev., 70, 6372, doi:10.1016/j.quascirev.2013.03.013, 2013.

Rohling, E. J., Marino, G., and Grant, K. M.: Mediterranean climate and oceanography, and the periodic development of anoxic events (sapropels), Earth-Sci. Rev., 143, 62-97, doi:10.1016/j.earscirev.2015.01.008, 2015.

Rossignol-Strick, M.: Mediterranean Quaternary sapropels, an immediate response of the African monsoon to variation of insolation, Palaeogeogr. Palaeoecol. 49, 237-263, doi:10.1016/00310182(85)90056-2, 1985.

Rubin, S., Ziv, B., and Paldor, N.: Tropical Plumes over Eastern North Africa as a Source of Rain in the Middle East, Monthly Weather Rev., 135, 4135-4148, doi:10.1175/2007mwr1919.1, 2007.

Sade, A., Hall, J. K., Sade, H., Amit, G., Tibor, G., Schulze, B., Gur-Arieh, L., ten Brink, U., Ben-Avraham, Z., Keller, C., Gertman, I., Beaudoin, J., Al-Zoubi, A., Akawwi, E., Rimawi, O., Abueladas, A., Mayer, L., Calder, B., and Maratos, A.: Multibeam Bathymetric Map of the Dead Sea, Geological Survey of Israel Report GSI/01, 2014.

Sánchez Goñi, M. F., Eynaud, F., Turon, J. L., and Shackleton, N. J.: High resolution palynological record off the Iberian margin: direct land-sea correlation for the Last Interglacial complex, Earth Planet. Sci. Lett., 171, 123-137, doi:10.1016/S0012821X(99)00141-7, 1999.

Sneh, A., Bartov, Y., Weissbrod, T., Rosensaft, M.: Geological Map of Israel, 1 : 200 000, Israel Geological Survey (4 sheets), 1998.

Stein, M., Starinsky, A., Katz, A., Goldstein, S. L., Machlus, M., and Schramm, A.: Strontium isotopic, chemical, and sedimentological evidence for the evolution of Lake Lisan and the Dead Sea, Geochim. Cosmochim. Ac., 61, 3975-3992, doi:10.1016/s0016-7037(97)00191-9, 1997.

Stein, M., Torfstein, A., Gavrieli, I., and Yechieli, Y.: Abrupt aridities and salt deposition in the post-glacial Dead Sea and their North Atlantic connection, Quaternary Sci. Rev., 29, 567-575, doi:10.1016/j.quascirev.2009.10.015, 2010.

Stein, M., Ben-Avraham, Z., and Goldstein, S. L.: Dead Sea deep cores: A window into past climate and seismicity, EOS, Transactions American Geophysical Union, 92, 453-454, doi:10.1029/2011eo490001, 2011.

Svendsen, J. I., Alexanderson, H., Astakhov, V. I., Demidov, I., Dowdeswell, J. A., Funder, S., Gataullin, V., Henriksen, M., Hjort, C., Houmark-Nielsen, M., Hubberten, H. W., Ingólfsson, Ó., Jakobsson, M., Kjær, K. H., Larsen, E., Lokrantz, H., Lunkka, J. P., Lyså, A., Mangerud, J., Matiouchkov, A., Murray, A., Möller, P., Niessen, F., Nikolskaya, O., Polyak, L., Saarnisto, M., Siegert, C., Siegert, M. J., Spielhagen, R. F., and Stein, R.: Late Quaternary ice sheet history of northern Eurasia, Quaternary Sci. Rev., 23, 1229-1271, doi:10.1016/j.quascirev.2003.12.008, 2004. 
Tjallingii, R., Claussen, M., Stuut, J.-B. W., Fohlmeister, J., Jahn, A., Bickert, T., Lamy, F., and Rohl, U.: Coherent high- and lowlatitude control of the northwest African hydrological balance, Nat. Geosci., 1, 670-675, 2008.

Torfstein, A., Gavrieli, I., Katz, A., Kolodny, Y., and Stein, M.: Gypsum as a monitor of the paleo-limnological-hydrological conditions in Lake Lisan and the Dead Sea, Geochim. Cosmochim. Ac., 72, 2491-2509, doi:10.1016/j.gca.2008.02.015, 2008.

Torfstein, A., Haase-Schramm, A., Waldmann, N., Kolodny, Y., and Stein, M.: U-series and oxygen isotope chronology of the mid-Pleistocene Lake Amora (Dead Sea basin), Geochim. Cosmochim. Ac., 73, 2603-2630, doi:10.1016/j.gca.2009.02.010, 2009.

Torfstein, A., Goldstein, S. L., Stein, M., and Enzel, Y.: Impacts of abrupt climate changes in the Levant from Last Glacial Dead Sea levels, Quaternary Sci. Rev., 69, 1-7, doi:10.1016/j.quascirev.2013.02.015, 2013.

Torfstein, A., Goldstein, S. L., Kushnir, Y., Enzel, Y., Haug, G., and Stein, M.: Dead Sea drawdown and monsoonal impacts in the Levant during the last interglacial, Earth Planet. Sci. Lett., 412, 235-244, doi:10.1016/j.eps1.2014.12.013, 2015.

Tubi, A. and Dayan, U.: Tropical Plumes over the Middle East: Climatology and synoptic conditions, Atmos. Res., 145-146, 168181, doi:10.1016/j.atmosres.2014.03.028, 2014.

Tzedakis, P. C.: Towards an understanding of the response of southern European vegetation to orbital and suborbital climate variability, Quaternary Sci. Rev., 24, 1585-1599, doi:10.1016/j.quascirev.2004.11.012, 2005.

Tzedakis, P. C.: Seven ambiguities in the Mediterranean palaeoenvironmental narrative, Quaternary Sci. Rev., 26, 2042-2066, doi:10.1016/j.quascirev.2007.03.014, 2007.

Vaks, A., Bar-Matthews, M., Matthews, A., Ayalon, A., and Frumkin, A.: Middle-Late Quaternary paleoclimate of northern margins of the Saharan-Arabian Desert: reconstruction from speleothems of Negev Desert, Israel, Quaternary Sci. Rev., 29, 2647-2662, doi:10.1016/j.quascirev.2010.06.014, 2010.

Waldmann, N., Starinsky, A., and Stein, M.: Primary carbonates and Ca-chloride brines as monitors of a paleo-hydrological regime in the Dead Sea basin, Quaternary Sci. Rev., 26, 2219-2228, doi:10.1016/j.quascirev.2007.04.019, 2007.

Waldmann, N., Stein, M., Ariztegui, D., and Starinsky, A.: Stratigraphy, depositional environments and level reconstruction of the last interglacial Lake Samra in the Dead Sea basin, Quaternary Res., 72, 1-15, doi:10.1016/j.yqres.2009.03.005, 2009.
Waldmann, N., Torfstein, A., and Stein, M.: Northward intrusions of low- and mid-latitude storms across the SaharoArabian belt during past interglacials, Geology, 38, 567-570, doi:10.1130/g30654.1, 2010.

Waldmann, N., Hadzhiivanova, E., Neugebauer, I., Brauer, A., Schwab, M. J., Frank, U., and Dulski, P.: Anatomy of mass transport deposits in the Dead Sea; sedimentary processes in an active tectonic hypersaline basin, EGU General Assembly, EGU-201411281, Vienna, Austria, 2014,

Webb III, T., Ruddiman, W. F., Street-Perrott, F. A., Markgraf, V., Kutzbach, J. E., Bartlein, P. J., Wright Jr., H. E., and Prell, W. L.: Climatic changes during the past 18000 years: regional syntheses, mechanisms, and causes, in: Global Climates since the Last Glacial Maximum, edited by: Wright Jr., H. E., Kutzbach, J. E., and Webb III, T., 514-535, 1993.

Weltje, G. J. and Tjallingii, R.: Calibration of XRF core scanners for quantitative geochemical logging of sediment cores: Theory and application, Earth Planet. Sci. Lett., 274, 423-438, doi:10.1016/j.eps1.2008.07.054, 2008.

Wolff, E. W., Chappellaz, J., Blunier, T., Rasmussen, S. O., and Svensson, A.: Millennial-scale variability during the last glacial: The ice core record, Quaternary Sci. Rev., 29, 2828-2838, doi:10.1016/j.quascirev.2009.10.013, 2010.

Wright, J. D.: Global Climate Change in Marine Stable Isotope Records, in: Quaternary Geochronology: Methods and Applications, edited by: Noller, J. S., Sowers, J. M., and Lettis, W. R., Am. Geophys. Union, 427-433, 2000.

Yechieli, Y., Magaritz, M., Levy, Y., Weber, U., Kafri, U., Woelfli, W., and Bonani, G.: Late Quaternary Geological History of the Dead Sea Area, Israel, Quaternary Res., 39, 59-67, doi:10.1006/qres.1993.1007, 1993.

Yechieli, Y., Gavrieli, I., Berkowitz, B., and Ronen, D.: Will the Dead Sea die?, Geology, 26, 755-758, doi:10.1130/00917613(1998)026<0755:wtdsd> 2.3.co;2, 1998.

Ziv, B., Dayan, U., Kushnir, Y., Roth, C., and Enzel, Y.: Regional and global atmospheric patterns governing rainfall in the southern Levant, Int. J. Climatol., 26, 55-73, doi:10.1002/joc.1238, 2006. 